\title{
Historical Landscape Use of Migratory Caribou: New Insights From Old Antlers
}

\begin{abstract}
Joshua H. Miller ${ }^{1 *}$, Brooke E. Crowley ${ }^{1,2}$, Clément P. Bataille ${ }^{3}$, Eric J. Wald ${ }^{4 \dagger}$, Abigail Kelly ${ }^{1}$, Madison Gaetano ${ }^{1}$, Volker Bahn ${ }^{5}$ and Patrick Druckenmiller ${ }^{6}$

${ }^{1}$ Department of Geology, University of Cincinnati, Cincinnati, OH, United States, ${ }^{2}$ Department of Anthropology, University of Cincinnati, Cincinnati, $\mathrm{OH}$, United States, ${ }^{3}$ Department of Earth and Environmental Sciences, University of Ottawa, Ottawa, ON, Canada, ${ }^{4}$ Arctic National Wildlife Refuge, U.S. Fish and Wildlife Service, Fairbanks, AK, United States, ${ }^{5}$ Department of Biological Sciences, Wright State University, Dayton, $\mathrm{OH}$, United States, ${ }^{6}$ Department of Geosciences, University of Alaska Fairbanks and University of Alaska Museum, Fairbanks, AK, United States
\end{abstract}

Accumulations of shed caribou antlers (Rangifer tarandus) are valuable resources for expanding the temporal scope with which we evaluate seasonal landscape use of herds.

OPEN ACCESS

Edited by:

Jennifer Leonard,

Consejo Superior de Investigaciones Cientificas (CSIC), Spain

Reviewed by:

James Schaefer,

Trent University, Canada Pam Groves, University of Alaska Fairbanks, United States

*Correspondence: Joshua H. Miller josh.miller@uc.edu

${ }^{\dagger}$ Present address: Eric J. Wald, Inventory and Monitoring Program, National Park Service, Fairbanks, AK, United States

Specialty section:

This article was submitted to Paleoecology

a section of the journal

Frontiers in Ecology and Evolution

Received: 03 August 2020 Accepted: 16 December 2020 Published: 22 January 2021

Citation:

Miller JH, Crowley BE, Bataille $C P$, Wald EJ, Kelly A, Gaetano M, Bahn V and Druckenmiller $P$ (2021) Historical Landscape Use of Migratory Caribou:

New Insights From Old Antlers.

Front. Ecol. Evol. 8:590837.

doi: $10.3389 /$ fevo.2020.590837
Female caribou shed their antlers within days of giving birth, thus marking calving ground locations. Antler geochemistry $\left({ }^{87} \mathrm{Sr} /{ }^{86} \mathrm{Sr}\right)$ reflects the isotopic signature of regions used during antler growth, thereby providing data on a second component of seasonal landscape use. Here, we evaluate shed caribou antlers from the Coastal Plain of the Arctic National Wildlife Refuge, Alaska. The Central and Eastern regions of the Coastal Plain are calving grounds for the Porcupine Caribou Herd, while the Western Coastal Plain supports calving by the Central Arctic Herd. We found that antler ${ }^{87} \mathrm{Sr} /{ }^{86} \mathrm{Sr}$ from the Central and Eastern Coastal Plain were isotopically indistinguishable, while antler ${ }^{87} \mathrm{Sr} /{ }^{86} \mathrm{Sr}$ from the Western Coastal Plain was significantly smaller. For each region, we compared isotopic data for "recent" antlers, which overlap the bulk of standardized state and federal caribou monitoring (early 1980s and younger), with "historical" antlers shed in years predating these records (from the 1300s to the 1970s). For Porcupine Herd females calving in the Arctic Refuge, comparisons of antler ${ }^{87} \mathrm{Sr} /{ }^{86} \mathrm{Sr}$ through time indicate that summer ranges have been consistent since at least the 1960s. However, changes between historical and recent antler ${ }^{87} \mathrm{Sr} /{ }^{86} \mathrm{Sr}$ for the Central Arctic Herd indicate a shift in summer landscape use after the late 1970s. The timing of this shift is coincident with multiple factors including increased infrastructural development in their range related to hydrocarbon extraction. Accumulations of shed caribou antlers and their isotope geochemistry extend modern datasets by decades to centuries and provide valuable baseline data for evaluating potential anthropogenic and other influences on caribou migration and landscape use.

Keywords: conservation paleobiology, historical ecology, seasonal landscape use, strontium isotope ratios, ANWR

\section{INTRODUCTION}

Seasonal landscape use is a core component of animal ecology and population biology and is influenced by a variety of factors including population size, climate, and anthropogenic impacts (Fryxell and Sinclair, 1988; Dingle, 2006; Avgar et al., 2014). Many of these drivers operate on decadal timescales or longer, but datasets rarely have the temporal depth to capture their 
underlying long-term variability, trends, or oscillations (Vors and Boyce, 2009; Magurran et al., 2010; Mihoub et al., 2017). Additionally, the scale of ecological changes due to natural and anthropogenic influences is often masked because wildlife monitoring programs generally start after populations had been subjected to significant perturbations (Terry, 2009; Tomasovych and Kidwell, 2017). The need for datasets that extend beyond the temporal restrictions of available biomonitoring data is particularly critical for species living in regions with high rates of climate-related environmental change (e.g., the Arctic) or dependent on ecological strategies, such as migration, that are particularly threatened by anthropogenic impacts (Berger, 2004; Festa-Bianchet et al., 2011; Tucker et al., 2018). While historical ecology remains mostly lost to time, an increasing number of ecological proxies can help quantify the magnitude and directions of otherwise cryptic biological changes, including aspects of landscape use and migration (Morneau and Payette, 1998, 2000; Zalatan et al., 2006; Kidwell, 2007; Froyd and Willis, 2008; Behrensmeyer and Miller, 2012; Kidwell and Tomasovych, 2013; Miller et al., 2013; Dietl et al., 2015; Barnosky et al., 2017; Grace et al., 2019).

Bones are one such proxy, as they can persist on landscape surfaces for decades, centuries, or longer and can faithfully record data on their source populations (Behrensmeyer, 1978; Andrews, 1995; Sutcliffe and Blake, 2000; Western and Behrensmeyer, 2009; Miller, 2011; Behrensmeyer and Miller, 2012; Miller et al., 2013). In addition to data on species presence and relative abundances through time, some skeletal materials are capable of recording patterns of seasonal landscape use. Antlers of deer (Cervidae) are grown and shed following seasonal schedules (Espmark, 1971; Bergerud, 1976; Hall, 2005). After decades, shed antlers can accumulate into measurable densities on landscape surfaces (e.g., $10^{2}-10^{3}$ antlers $/ \mathrm{km}^{2}$ ), with regions of relatively high or low antler densities faithfully recording the herd's patterns of seasonal landscape use (Miller and Barry, 1992; Miller, 2012; Miller et al., 2013).

Caribou (Rangifer tarandus) are unique among cervids in that both females and males can annually grow and shed antlers (Espmark, 1971; Bergerud, 1976). Differences in antler size and morphology enable sex determination (Høymork and Reimers, 1999; Miller et al., 2013), opening opportunities to evaluate patterns of sex-specific landscape use. In caribou, timing of antler shedding depends on maturity, sex, and other hormonal drivers. Mature males, for example, shed antlers shortly after fall mating, while immature males may keep them until spring (Bergerud, 1976; Blake et al., 1998). Females that do not become pregnant either shed their antlers following the fall mating season or keep them until early spring (several weeks or more before pregnant caribou give birth; Espmark, 1971; Bubenik et al., 1997). Notably, pregnant female caribou retain their antlers until the spring calving season and only shed them within a few days before or after giving birth (Espmark, 1971; Bergerud, 1976; Whitten, 1995). The calving period is highly conserved annually, with peak calving date for individual herds varying on the scale of days (Griffith et al., 2002). Tens-of-thousands of pregnant females may visit calving grounds each year, resulting in large accumulations of shed female antlers $\left(10^{2}-10^{3}\right.$ antlers $\left./ \mathrm{km}^{2}\right)$ that can be used as a geographic proxy for mapping both recent and historical calving grounds (Miller et al., 2013).

While locations of shed antlers document landscape use during the shedding period, antler isotope geochemistry can provide complementary ecological information on landscape use during antler growth. Strontium isotope ratios $\left({ }^{87} \mathrm{Sr} /{ }^{86} \mathrm{Sr}\right)$ of bone, tooth, hair, and antlers are a broadly used tool in forensic science, ecology, archeology, and paleoecology to help track the geographic origins of biological tissues (reviewed by Bentley, 2006; Hobson et al., 2009; Makarewicz and Sealy, 2015; Crowley et al., 2017). This is possible because bioavailable ${ }^{87} \mathrm{Sr} /{ }^{86} \mathrm{Sr}$ varies across landscapes primarily in response to changes in surface geology (Capo et al., 1998; Crowley et al., 2017; Bataille et al., 2020). As strontium ions can replace calcium during the formation of biological tissues, ${ }^{87} \mathrm{Sr} /{ }^{86} \mathrm{Sr}$ can be sequestered in bones, teeth, and other calcium-rich structures (Koch et al., 1995; Capo et al., 1998; Hobson et al., 2009). Developing tissue can record the isotopic signatures of the strontium source because this replacement occurs with negligible, and correctable, fractionation (Flockhart et al., 2015; Lewis et al., 2017). By first establishing how strontium isotope ratios change across space, the ${ }^{87} \mathrm{Sr} /{ }^{86} \mathrm{Sr}$ in biological materials (modern and fossil) can provide geographic context to specimens including deciphering patterns of landscape use and migration (Hoppe and Koch, 2007; Britton et al., 2009; Gigleux et al., 2017; Widga et al., 2017; Bataille et al., 2018, 2020).

In this study, we tested the capacity of antler ${ }^{87} \mathrm{Sr} /{ }^{86} \mathrm{Sr}$ to discriminate between two caribou herds (Porcupine and Central Arctic) that calve on different regions of the Coastal Plain within the Arctic National Wildlife Refuge, Alaska (USA, Figure 1). Alaskan caribou calve primarily in early June (Cameron et al., 2002; Griffith et al., 2002; Nicholson et al., 2016), and subsequent re-growth of female antlers occurs following calving and during the summer (Bergerud, 1976; Bubenik et al., 1997). Thus, antler ${ }^{87} \mathrm{Sr} /{ }^{86} \mathrm{Sr}$ should primarily reflect bioavailable ${ }^{87} \mathrm{Sr} /{ }^{86} \mathrm{Sr}$ from a caribou's post-calving spring and summer ranges. Based on mapped geological differences between summer ranges of the Porcupine and Central Arctic Herds (Figure 1; Wilson et al., 2015), we predict that antlers collected from the Central and Eastern Coastal Plain (calving grounds of the Porcupine Herd) will be isotopically distinct from antlers collected from the Western Coastal Plain (Central Arctic Herd calving grounds).

We also used antler ${ }^{87} \mathrm{Sr} /{ }^{86} \mathrm{Sr}$ to test for changes in summer landscape use for the Porcupine and Central Arctic Herds. Because bone weathering is slow in arctic settings (Meldgaard, 1986; Sutcliffe and Blake, 2000), it is likely that some antlers lying on the calving grounds were shed hundreds of years ago. We used antler weathering characteristics and radiocarbon dating to identify antlers from different time periods and test for changes in landscape use $\left({ }^{87} \mathrm{Sr} /{ }^{86} \mathrm{Sr}\right)$ through time. Since surveys of the Central Arctic Herd began in the 1970s, there have been dramatic increases in petroleum-related infrastructure in portions of their calving, summer, and winter ranges (Fancy, 1983; Fancy et al., 1989; Cameron et al., 1992; Nicholson et al., 2016) as well as dramatic changes in herd size (Lenart, 2015; Curl, 2020; Johnson et al., 2020). Both of these factors could have impacted patterns of seasonal landscape use (Bergerud, 


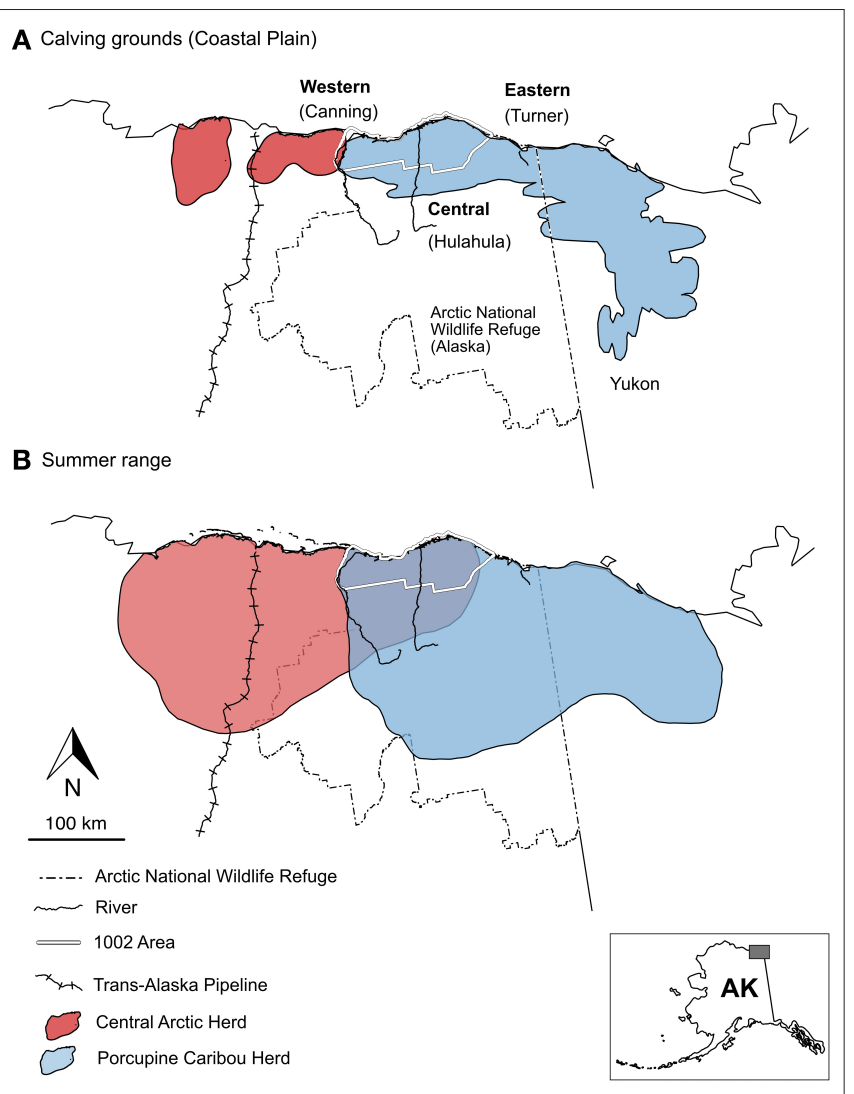

FIGURE 1 | Seasonal ranges for caribou of the Arctic National Wildlife Refuge, AK. Ranges of the Central Arctic (red) and Porcupine Herds (blue) are distinct during (A) calving periods, but there is greater spatial overlap across their (B) summer ranges. Antler surveys were conducted along the Coastal Plain calving grounds, accessed by major river systems; Canning River (Western Coastal Plain), Hulahula River (Central Coastal Plain), and Turner River (Eastern Coastal Plain). The Trans-Alaska Pipeline (cross-hatched line) was completed in 1977. Herd range boundaries from Trammell et al. (2015).

1996; Boertje and Gardner, 2000; Hinkes et al., 2005; Vistnes and Nellemann, 2008; Nicholson et al., 2016). Across a similar time period, the Porcupine Herd experienced relatively limited anthropogenic development of their range and comparatively less dramatic changes in population size (Griffith et al., 2002; Caikoski, 2020). We therefore expect that landscape use of the Porcupine Herd has been more consistent through time.

\section{MATERIALS AND METHODS}

\section{The Caribou Study System}

The Arctic National Wildlife Refuge (Arctic Refuge) is ideally suited to evaluate the geographic and seasonal data recorded in antlers of migratory caribou. The Coastal Plain of the Arctic Refuge is a broad, flat, tussock-tundra-rich landscape used as a caribou calving ground by the Porcupine Herd and the Central Arctic Herd (Figure 1; Cameron et al., 2002; Griffith et al., 2002; Jorgenson et al., 2002; Jorgenson and Walker, 2018). Most calving activity in the Arctic Refuge is by Porcupine Herd females, which generally enter the Coastal Plain from the east and south (Fancy et al., 1989; Griffith et al., 2002). Caribou that calve along the western margin of the Arctic Refuge's Coastal Plain are mostly from the Central Arctic Herd, whose calving grounds are predominately west of the Arctic Refuge (Figure 1; Fancy et al., 1989; Cameron et al., 2002; Nicholson et al., 2016; Prichard et al., 2020). While geographically separated during calving, the current ranges of the Porcupine and Central Arctic Herds partially overlap during summers (on the Coastal Plain) and winters (generally south of the Brooke Range; Lenart, 2015; Nicholson et al., 2016; Prichard et al., 2020). Yet even with this overlap, the overall geology of summer ranges is distinct, which is important for differentiating herds using antler ${ }^{87} \mathrm{Sr} /{ }^{86} \mathrm{Sr}$. The summer ranges of both herds overlay unconsolidated Quaternary sediments, but the range of the Porcupine Herd extends east and south into regions dominated by metasediments, mafic rocks, and Neoproterozoic siliciclastic rocks (Wilson et al., 2015; Colpron et al., 2016), while the range of the Central Arctic Herd extends west into areas richer in Mesozoic carbonates as well as Mesozoic and Cenozoic siliciclastic rocks (Wilson et al., 2015).

The Central Arctic and Porcupine Herds have been studied for decades by state, territorial, and federal offices of the US and Canada (Russell et al., 1993, 2005; Cameron et al., 2002; Griffith et al., 2002; Russell and Gunn, 2019; Caikoski, 2020). The long history of evaluation is due, in part, to Alaska's rich oil reserves and mandates to consider the consequences of petroleum development on caribou ecology and herd sizes across Alaska (USA-Canada, 1987; Whitten, 1994; Griffith et al., 2002; Cameron et al., 2005; Russell and Gunn, 2019). Within the Arctic Refuge, significant work has focused on a region of the Coastal Plain referred to as the "1002 Area" (Figure 1), which includes the majority of the Porcupine Herd's Alaskan Coastal Plain calving grounds (Griffith et al., 2002; Caikoski, 2020). In 1980, the United States Congress excluded this region from many long-term protections bestowed on most wildlife refuge lands and it was established as a region for possible hydrocarbon development (Udall, 1980). Lease sales for hydrocarbon development were mandated by the U.S. Congress in 2017 (Brady, 2017). In this context, many management questions related to the Arctic Refuge's Coastal Plain have focused on assessing the potential ecological consequences of developing the 1002 Area (Cameron and Whitten, 1980; Cameron et al., 1992, 2005; Griffith et al., 2002; Arthur and Del Vecchio, 2009; Pearce et al., 2018; Russell and Gunn, 2019). Thus, a pertinent question for this study is whether antler records provide new information on how caribou use this region.

The size and location of caribou ranges are determined by endogenous and exogenous drivers, including herd size and anthropogenic stressors (Skoog, 1968; Russell et al., 1993; Bergerud, 1996; Cameron et al., 2005; Hinkes et al., 2005). Human infrastructural developments can produce clear and sustained impacts on caribou landscape use (Vistnes and Nellemann, 2008; Johnson and Russell, 2014). This is most clearly seen as avoidance of developed areas such as tourist lodging and infrastructure supporting petroleum exploration (Klein, 1971; Helle and Särkelä, 1993; Vors et al., 2010; Wilson et al., 2016). Roads, particularly when they run perpendicular 
to the direction of migration, can also represent significant barriers to caribou movement and delay the arrival of females to calving grounds (Bolger et al., 2008; Wilson et al., 2016). Caribou may also shift or functionally abandon portions of seasonal ranges due to development (Cameron et al., 1992, 2005; Joly et al., 2006). Population size and climate also impact caribou landscape use, but do so more cyclically. For example, caribou populations can fluctuate decadally by tens- to hundredsof-thousands of individuals (Vors and Boyce, 2009), often influenced by hemispheric climate cycles (Griffith et al., 2002; Joly et al., 2011). Large changes in population can lead to changes in overall geographic range and even influence whether caribou undergo annual migrations at all or become more sedentary (Bergerud, 1996; Baltensperger and Joly, 2019).

The Central Arctic Herd was first identified in 1975, but the herd's range has been subjected to petroleum development since the 1960s (Bergerud, 1996; Hinkes et al., 2005). This development includes the Trans-Alaska Pipeline (completed in 1977), and scores of subsequent drill sites and roadways connecting oil fields across calving and summer ranges (Figure 1; Fancy et al., 1989; Arthur and Del Vecchio, 2009). There has been widespread interest in evaluating herd impacts from economic development, including changes in landscape use in response to oil fields and other developments, and reduced body weight for calves in closer proximity to roads and drilling operations (Dau and Cameron, 1986; Cameron et al., 1992; Lawhead and Prichard, 2003; Arthur and Del Vecchio, 2009; Nicholson et al., 2016). The population of the Central Arctic Herd has also changed dramatically across the available timeseries, increasing from ca. $5,000-6,000$ to 28,000 individuals during the 1970 s and 1990 s, before increasing again to 68,000 in 2010 and subsequently falling to 23,000 in 2016 (Cameron and Whitten, 1979; Whitten and Cameron, 1983; Cameron et al., 2005; Lenart, 2015; Curl, 2020; Johnson et al., 2020). In 2019, the herd was estimated at 30,000 individuals (Curl, 2020). The Central Arctic Herd calving grounds are concentrated in two core regions on the Coastal Plain, one of which overlaps the western margin of the Arctic Refuge. The summer range of the herd incorporates a broad section of the Coastal Plain and Brooks Range foothills within the Arctic Refuge and extends to the west (Figure 1; Cameron et al., 2002; Nicholson et al., 2016).

The Porcupine Herd has been monitored since the 1960s and 1970s, with particular emphasis on population size, patterns of landscape use, the geographic covariates of calf survivorship, and other core components of population biology (Skoog, 1968; Whitten et al., 1984, 1992; Fancy et al., 1989; Fancy and Whitten, 1991; Bergerud, 1996; Griffith et al., 2002; PCMB, 2016). Population estimates show that the Porcupine Herd increased from 100,000 to 178,000 individuals between the 1970s and 1989, before falling to 123,000 in 2001 (Caikoski, 2020). The herd then increased from 168,000 to 218,000 between 2010 and 2017 (Caikoski, 2020). Unlike the Central Arctic Herd, the annual range of the Porcupine Herd has been subjected to less infrastructural and economic activity (Fancy et al., 1989; Griffith et al., 2002; PCMB, 2016). For both herds, data on seasonal landscape use and migration have become more robust with increased numbers of radio-collared (and now GPS-collared) caribou and the standardization of survey and data processing protocols starting in the 1980s (Griffith et al., 2002; Caikoski, 2020). The calving grounds of the Porcupine Herd encompass nearly the entire Coastal Plain of the Arctic Refuge and extend into Yukon, Canada. The summer range extends from the Coastal Plain to the Brooks Range in both Alaska and Yukon (Figure 1; Fancy et al., 1989; Russell et al., 1993; Griffith et al., 2002).

\section{Specimen Collection and Selection}

Antlers for this study were selected from collections for a larger study on arctic bone weathering and caribou landscape use (e.g., Miller et al., 2013). Shed caribou antlers were collected from tundra surfaces along the Arctic Refuge Coastal Plain in the summers of 2010-2012, 2014, and 2015 (Figure 1). We used major river systems to collect antlers from three regions of the Coastal Plain: Western (Canning River), Central (Hulahula and Jago Rivers), and Eastern (Turner and Kongakut Rivers). From west to east, this sampling extends across $100 \mathrm{~km}$. The river systems extend northward from the Brooks Range to the Arctic Ocean, and thus provide opportunities to sample across the width of the Coastal Plain (ca. 10-70 km; Figure 1).

Antlers were collected by walking across tundra surfaces using standardized surveys of well-drained tundra habitats rich in the low-growing evergreen flowering plant, Dryas (Dryas river terraces, sensu Jorgenson et al., 2002; Jorgenson and Walker, 2018). Dryas terraces are generally found within a few kilometers of river channels. Survey sites were accessed by fixedwing aircraft or by rafting down rivers to survey locations. On Dryas terraces, the ground is not visually obstructed by tussocks, willows, or other vegetation that would hamper antler observation; this makes antlers highly visible and readily sampled (Miller et al., 2013). Surveys and collections were done with permission from, and in collaboration with, the Arctic National Wildlife Refuge (United States Fish and Wildlife Service).

While distinguishing female antlers from much larger and more palmated adult male antlers is straightforward, differentiating antlers of adult females from similarly sized and shaped young males requires careful evaluation (Høymork and Reimers, 1999; Miller et al., 2013). To categorize antlers by sex, we used museum reference collections and measurements of the major and minor axis of the roughly elliptical pedicle attachment surface (Miller et al., 2013). For each specimen, calculations provide a mean probability and $95 \%$ confidence interval that the antler is female (Miller et al., 2013). Female antlers dominate our dataset $(n=57)$, but to provide preliminary ${ }^{87} \mathrm{Sr} /{ }^{86} \mathrm{Sr}$ comparisons between the sexes, we also included a small number of males from the Central and Eastern Coastal Plain $(n=7)$. One antler could not be confidently assigned to either sex and is excluded from comparisons between males and females.

Shed antlers can be identified by the presence of an exposed antler-skull attachment surface. All but two antlers reported here were shed. The first exception (T01-20-14 09) is the proximal portion of a female antler that is still attached to a fragment of the cranium. This specimen shows clear bone resorption along the antler attachment surface, which we interpret as strong evidence that shedding was underway and that this individual died during the calving season. The second antler (ANWR-120) is a male that 
includes a section of the antler pedicle and is also interpreted as a mortality. Both specimens were included because they are heavily weathered and likely predate available biomonitoring data by at least several decades. While some antlers were partially obscured in tundra or moss, all were at least partially exposed. One antler (T01-14-12 14) was found fully exposed, but almost entirely covered in root etching and was likely previously buried. This specimen was also included for its likely antiquity.

To test for change in seasonal landscape use through time, we selected antlers from our collection that spanned a potentially wide range of ages; methods for discriminating antler age categories are described below ("dating antlers"). Antlers were categorized as "recent" or "historical" depending on whether they were shed in years that overlapped the best-available caribou management records and/or following infrastructure development on herd ranges. This distinction is separately evaluated for the Porcupine and Central Arctic Herds due to their different management histories. For antlers from the Central and Eastern Coastal Plain (calving grounds of the Porcupine Herd), the dividing date between historical and recent was 1983. This division corresponds to standardization of calving surveys for the Porcupine Herd and when the numbers of radio-collared females began to substantially increase (Griffith et al., 2002). For antlers from the Western Coastal Plain (calving grounds of the Central Arctic Herd), the dividing date between historical and recent was 1980 to coincide with the completion of many infrastructural development projects and the onset of several others (Fancy et al., 1989; Cameron et al., 1992). Results were consistent when using the same cutoff for both regions (i.e., 1980 or 1983). We selected equivalent samples of "recent" $(n=34)$ and "historical" $(n=31)$ antlers from each of the three regions of the Coastal Plain $\left(n_{\text {median }}\right.$ $=10 ; n_{\text {range }}=[9,13]$, female only: $\left.n_{\text {median }}=10, n_{\text {range }}=[8,10]\right)$.

\section{Dating Antlers}

To assign antlers as either historical or recent, we estimated growth year using a combination of antler weathering analysis and Accelerator Mass Spectrometry (AMS) radiocarbon dating. Historical antlers were first identified by their advanced weathering and confirmed by AMS dates. To identify recent antlers without needing to directly date all specimens, we calibrated the progression of early weathering using a second series of AMS dates.

Bones in many environments progress beyond initial stages of weathering (weathering stages 0 and 1; sensu Behrensmeyer, 1978) within a few years (Behrensmeyer, 1978; Miller, 2009). However, bone weathering rates are dramatically slowed in arctic settings (results below; Meldgaard, 1986; Sutcliffe and Blake, 2000). By observing antler weathering patterns, it became apparent that the progressive loss of original bone textures was a potential indicator of initial weathering duration. We defined original bone textures as smooth, unmodified bone surfaces that may or may not maintain a glossy shine. The simplicity of the definition means antler surfaces can be readily assessed as original or modified. This definition is also non-ambiguous and highly restrictive as to which surfaces are considered original. Small cracks, slight roughening of external cortical surfaces, and

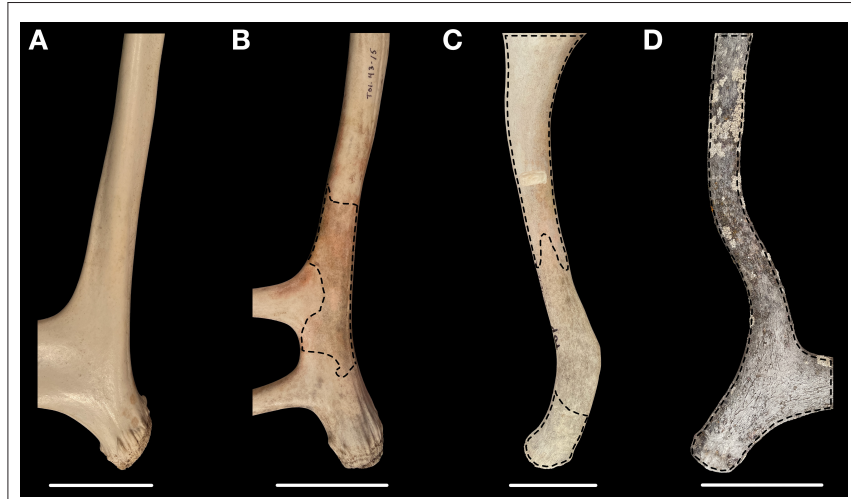

FIGURE 2 | Examples of antlers in the four weathering categories of original bone texture. (A) Bone texture score 0: preservation of more than two-thirds of original bone texture. (B) Score 1: between one- and two-thirds original bone texture preserved. (C) Score 2: less than one-third original bone texture preserved. (D) Score 3: no original bone texture preserved. Dashed lines outline regions of modified bone. In (C), unmodified bone is difficult to visually differentiate due to discoloration, but these areas are smooth to the touch. Region sampled for ${ }^{87} \mathrm{Sr} /{ }^{86} \mathrm{Sr}$ is visible as a light colored area in the upper half of (C). After evaluating the skyward and groundward sides of each antler, scores are added to create a Composite Score of bone texture ranging from 0 (supermajority of original bone texture preserved) to 6 (no original bone texture preserved). Scale bars are $5 \mathrm{~cm}$. Photographed specimens are (A) ANWR-133, (B) T01-43-15 01, (C) T01-16-12 12, and (D) T01-32-14 15.

other subtle, yet easily identified deviations from original bone textures are all recognized as modifications.

To evaluate initial weathering, we visually and tactilely assessed the coverage of preserved original bone texture for all antlers and scored them using four categories (Figure 2): $0=$ more than two-thirds original bone texture preserved, 1 $=$ between one- and two-thirds preserved, $2=$ less than onethird preserved, and $3=$ no original bone texture remaining. We also recorded whether lichens were present or absent. Because lichens lead to pocked bone surfaces (Hospitaleche et al., 2011), antler surfaces covered in lichens were scored as 3 . For each antler, we separately evaluated skyward and groundfacing sides, because these surfaces can experience different weathering microhabitats (Behrensmeyer, 1978; Andrews and Whybrow, 2005). To standardize our assessments, we focused on the proximal portion of the main beam (Figure 3, shaded area of antler schematic). This region has fairly even thickness of dense cortical bone, which is important for consistently estimating bone weathering duration (Behrensmeyer, 1978). Focusing on this anatomical region is also appropriate because it must be at least partially preserved to identify the antler as shed. After evaluating original bone texture, we added scores from the skyward and groundward sides into a Composite Score of bone texture, ranging from 0 (supermajority of all original bone texture preserved) to 6 (no original bone texture preserved).

To calibrate Composite Scores of bone texture to weathering duration, we AMS dated antlers with Scores of $3(n=3), 4(n$ $=1), 5(n=2)$, and $6(n=29$; includes all antlers previously identified as "historical"). Antlers with no or limited signs of weathering (Composite Scores 0-2) were not dated to maximize 


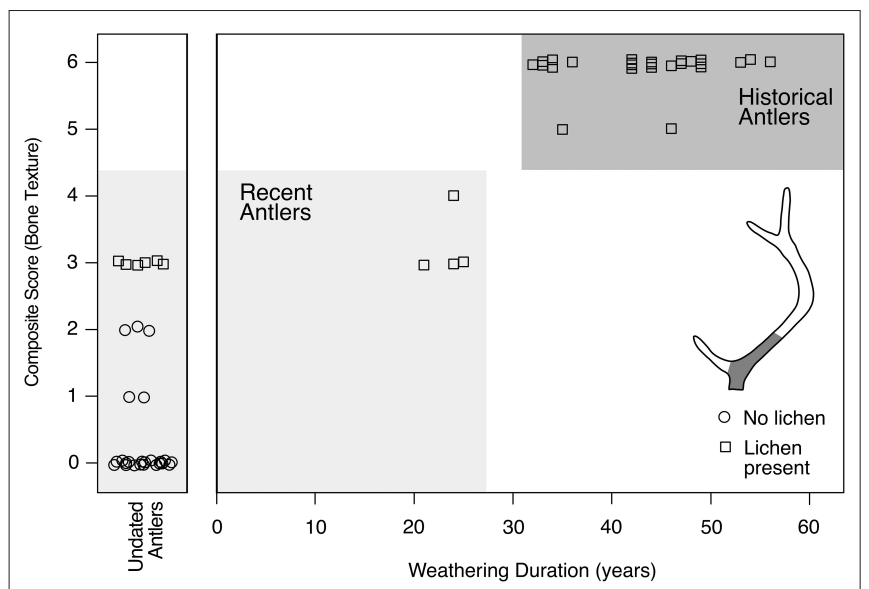

FIGURE 3 | Composite Scores of original bone texture calibrated to weathering duration. Weathering durations are calculated as the antler collection date minus the calibrated AMS date. Composite Scores range from 0 (super-majority of original bone textures preserved) to 6 (no original bone textures preserved). Composite Scores focus on the preservation of original surface textures of antlers. Composite Scores 0-5 characterize antlers in Weathering Stages 0 and 1 (Behrensmeyer, 1978). Antlers were evaluated along the proximal portion of the main beam (shaded area of antler schematic). Lichen presence or absence (squares or circles) is also indicated.

dates nearest the temporal divisions between "recent" and "historical." Further, progressions of bone weathering observed elsewhere instill confidence that antlers with no or minimal weathering have experienced the shortest weathering durations and are confidently "recent" (Behrensmeyer, 1978; Andrews and Whybrow, 2005; Miller, 2009; Western and Behrensmeyer, 2009).

For AMS dating, antlers were sampled from the proximal portion of the main beam. This region has dense cortical bone, which is resistant to contamination. Antlers were cut using a low-speed Dremel with a diamond wheel. Samples were cut into small chips and sent to the Keck-Carbon Cycle AMS Facility at the University of California, Irvine or the Center for Accelerator Mass Spectrometry at the Lawrence Livermore National Lab for chemical pretreatment and AMS dating. Collagen was prepared using standard treatments for demineralization and humic acid removal (Beaumont et al., 2010; Crowley et al., 2010), ultrafiltered, and lyophilized. For the 29 samples sent to the KeckCarbon Cycle AMS Facility (Supplementary Table 1), lipids were removed by sonicating antler chips in a 2:1 chloroform/methanol solution for $30 \mathrm{~min}$ prior to demineralization. This was repeated with a fresh chloroform/methanol solution until the solution was no longer cloudy. Samples were then sonicated for $30 \mathrm{~min}$ in methanol, and $30 \mathrm{~min}$ in Milli-Q water. The sonicator bath was cooled to keep the temperature below $60^{\circ} \mathrm{C}$. Of the six antlers dated at Lawrence Livermore, we only removed lipids from one (T03-02-11 28) by repeatedly sonicating in petroleum ether for 15 min until fat bubbles were no longer visible, and then rinsing with ultrapure water. There was no difference in $\delta^{13} \mathrm{C}$ values for antlers with $(n=30)$ or without $(n=5)$ lipid removal (Wilcoxon $U=78, p=0.81$ ), suggesting this should be of negligible concern for date corrections.
Radiocarbon dates were calibrated to calendar years using IntCal13 or BombNH13, depending on whether the antlers were grown before or after atmospheric nuclear weapons testing in the 1950s and 1960s (Hua et al., 2013; Reimer et al., 2013). We used the clam package in $\mathrm{R}$ to convert conventional ${ }^{14} \mathrm{C}$ dates into calendar years from which we report all date ranges and associated posterior probabilities within the $95 \%$ confidence interval of the calibrated date (Blaauw, 2019). From those probability distributions, we categorized antlers as "recent" (post 1980 or 1983 depending on location) or "historical" (pre 1980 or 1983) based on the age with the highest probability. While dating errors can be as small as a few years for antlers grown after the 1950s, dating uncertainties are greater for antlers grown prior to the 1950s (Uno et al., 2013). For these older antlers, we summarized their ages by calculating the weighted-mean of the age probability distribution, the 1-sigma variance around the mean, and the range of the $95 \%$ confidence interval (Telford et al., 2004; Blaauw, 2010).

Because of the swift spike and subsequent protracted decay of atmospheric radiocarbon produced by nuclear weapons testing in the 1950's, antlers grown after weapons testing can often be calibrated to two different sets of years (e.g., the 1960s and the 1980s; Reimer et al., 2004). Furthermore, even if antlers were grown during the earlier period of the post-bomb era (e.g., 1960s), the quick initial pulse of radiocarbon relative to slow subsequent decay can mean that antler radiocarbon may have more expansive overlap with later parts of the calibration curve (e.g., 1980s). Ultimately, this means that the most supported calibrated date may not always correctly identify whether an antler was grown in historical or recent times. Fortunately, antler weathering features can add meaningful independent data with which to evaluate the AMS calibration. When antler weathering was inconsistent with the most supported age-range of a bifurcated set of dates, we used weathering to inform which date range should be used.

\section{Strontium Isotope $\left({ }^{87} \mathrm{Sr} /{ }^{86} \mathrm{Sr}\right)$ Preparation and Analysis}

Antler samples were prepared for ${ }^{87} \mathrm{Sr} /{ }^{86} \mathrm{Sr}$ analysis following estalished protocols (Crowley and Wheatley, 2014; Baumann and Crowley, 2015; Crowley et al., 2018). Ca. $20 \mathrm{mg}$ of powder was milled from each antler using a low-speed Dremel with a burr attachment. We focused on a region of dense cortical bone roughly $15 \mathrm{~cm}$ from the base of the antler pedicle attachment and removed exterior bone surfaces in order to exclude weathered bone or other surface contaminants. Samples were soaked in 30\% hydrogen peroxide $\left(\mathrm{H}_{2} \mathrm{O}_{2}\right)$ at room temperature for $72 \mathrm{~h}$ and then rinsed five times with ultrapure water. Samples were agitated frequently, and $\mathrm{H}_{2} \mathrm{O}_{2}$ was refreshed after roughly $40 \mathrm{~h}$. Samples were then reacted with $1 \mathrm{M}$ acetic acid $\left(\mathrm{CH}_{3} \mathrm{COOH}\right)$ buffered with calcium acetate $\left(\mathrm{Ca}\left(\mathrm{C}_{2} \mathrm{H}_{3} \mathrm{O}_{2}\right)_{2}\right)$ at $4^{\circ} \mathrm{C}$ for $24 \mathrm{~h}$, rinsed five times with ultrapure water, and freeze dried.

Three to $5 \mathrm{mg}$ of each pretreated sample were sent to the Multicollector ICPMS Laboratory at the University of Illinois, Urbana-Champaign for strontium extraction and analysis. Samples were dissolved in $3 \mathrm{M}$ nitric acid $\left(\mathrm{H}_{2} \mathrm{NO}_{3}\right)$ and filtered 
through Eichrom $\mathrm{Sr}$-specific resin, followed by sequential rinsing with $0.05,3$, and $8 \mathrm{M} \mathrm{H}_{2} \mathrm{NO}_{3}$ to isolate strontium. Strontium was eluted from the resin with $3 \mathrm{~mL}$ of ultrapure water and $1 \mathrm{~mL}$ of $0.05 \mathrm{M} \mathrm{H}_{2} \mathrm{NO}_{3}$ into $4 \mathrm{~mL}$ autosampler vials. Samples were analyzed on a Nu Plasma high-resolution multicollector inductively-coupled plasma mass spectrometer. Data were corrected for drift using the international standard NBS 987 while two internal laboratory references ("Coral" and "E\&A") were used to monitor accuracy and precision.

\section{Analytical Framework}

To test if antler accumulations faithfully differentiate the Porcupine and Central Arctic Herds, we compared female antler ${ }^{87} \mathrm{Sr} /{ }^{86} \mathrm{Sr}$ from the Western, Central, and Eastern Coastal Plain using Levene tests for homogeneity of variance and pairwise Mann-Whitney $U$-tests with a Bonferroni correction. Comparisons were evaluated separately for historical and recent female antlers. To test for changes in female antler ${ }^{87} \mathrm{Sr} /{ }^{86} \mathrm{Sr}$ through time, we used Mann-Whitney $\mathrm{U}$ and Levene tests to compare recent and historical antlers from the same Coastal Plain region. We also tested whether male and female antler ${ }^{87} \mathrm{Sr} /{ }^{86} \mathrm{Sr}$ provides similar spatial information (Mann Whitney-U). To make our Bonferroni corrections more intuitive, our reported $p$-values have been multiplied by the number of comparisons; thus our target alpha value remains 0.05 . This is equivalent to adjusting the target alpha level itself by dividing by the number of comparisons. We used non-parametric tests in all analyses because the ${ }^{87} \mathrm{Sr} /{ }^{86} \mathrm{Sr}$ data deviate from normality (Sokal and Rohlf, 2011).

To estimate bioavailable ${ }^{87} \mathrm{Sr} /{ }^{86} \mathrm{Sr}$ on the Coastal Plain and surrounding regions, we used a modeled ${ }^{87} \mathrm{Sr} /{ }^{86} \mathrm{Sr}$ isoscape (Bataille et al., 2020). This model combines a global compilation of bioavailable ${ }^{87} \mathrm{Sr} /{ }^{86} \mathrm{Sr}$ in local plants, soils and animals, as well as geoenvironmental maps into a machine-learning regression to predict bioavailable ${ }^{87} \mathrm{Sr} /{ }^{86} \mathrm{Sr}$ at the global scale (1 km resolution). The model should work well for our purposes because the training data included soil, plant, and animal samples from Alaska. We used the latitude and longitude of each collected antler to extract the expected bioavailable ${ }^{87} \mathrm{Sr} /{ }^{86} \mathrm{Sr}$ at each collection site. To assess where antlers were grown, we applied a continuous-surface assignment framework available in the assignR package in $\mathrm{R}$ (Ma et al., 2020). This method compares the observed ${ }^{87} \mathrm{Sr} /{ }^{86} \mathrm{Sr}$ values $\left(x^{*}\right)$ with those predicted by the isoscape. We used the function assignR to calculate the likelihood $\left(z^{*}\right)$ that any given cell of the isoscape $(c)$ represents a potential origin for an antler $\left[f\left(z^{*} \mid c\right)\right]$ using a normal probability density function:

$$
f\left(z^{*} \mid c\right)=\left(\frac{1}{\sqrt{2 \pi}}\right) \exp \left[-\frac{z^{* 2}}{2}\right]
$$

with $z^{*}=\frac{x^{*}-\mu_{C}}{\sigma}$

where $\mu_{c}$ and $\sigma$ represents the mean and uncertainty at each pixel of the isoscape. We started by calculating probability surfaces for each female antler. We then summarized probabilities for each herd by summing the probability maps and dividing by the number of antlers sampled. These summary maps represent the average probabilities for each pixel. Map probabilities range from 0.0 (extremely low probability) to 1.0 (very high probability). Given this framework, we used female antler ${ }^{87} \mathrm{Sr} /{ }^{86} \mathrm{Sr}$ from the Western Coastal Plain to estimate regions of possible summer landscape use for the Central Arctic Herd and female antler ${ }^{87} \mathrm{Sr} /{ }^{86} \mathrm{Sr}$ from the Central and Eastern Coastal Plain to estimate regions of possible summer landscape use for the Porcupine Herd. All analyses were scripted in R version 3.4.1 (R Core Team, 2017).

\section{RESULTS}

\section{Antler Weathering and Radiocarbon Dating}

Composite Scores of original bone texture for all antlers and AMS dating results are available in Supplementary Tables 1, 2. As a reminder, our antler weathering analysis focused on the progressive loss of original bone textures, which only evaluates initial patterns of weathering. Antlers with Composite Scores 0-5 generally corresponded to antlers in the earliest weathering stages (WS 0-1; Behrensmeyer, 1978). Antlers that have lost all original bone textures (Composite Score 6) may be in any of the more advanced weathering stages (WS 2-5).

Weathering durations overlap for antlers that have lost most or all of their original bone texture (Composite Scores 5 and 6, Figure 3). Such antlers have been weathering for at least 32 years. Antlers with modestly better preservation (Composite Scores 3 and 4) have overlapping and tightly clustered weathering durations between 21 and 25 years. There is no overlap between Composite Score 3-4 antlers and those showing more advanced weathering (Composite Scores 5-6). We also found that lichens colonize antlers by the time antlers weather to Composite Score 3 (ca. 20 years; Figure 3, squares), after which they are a constant presence on subaerially exposed antlers.

All undated antlers had Composite Scores between 0 and 3 (Figure 3); the majority of which (21 of 30) exhibited only minimal weathering (Composite Scores 0-1). Clear distinction in weathering duration between more-weathered (Composite Scores 5-6) and less-weathered antlers (Composite Scores 4 and less) indicates that undated antlers have all been weathering for less than $\sim 25$ years. We thus conclude that antlers with Composite Scores 0-4, including all undated specimens, came from generations of caribou that overlap available management records, and are thus considered "recent" (Figure 3).

Two antlers had calibrated radiocarbon dates for which the most supported date range was inconsistent with antler weathering. These were T01-16-12 06 (Western Coastal Plain) and T01-42-15 78 (Eastern Coastal Plain). Both antlers have lost all original bone texture (Composite Score 6). T01-161206 has substantial bone surface cracking and flaking (akin to a shallowly developed Weathering Stage 2, Behrensmeyer, 1978). The calibrated age range for T01-16-12 06, which was collected in 2012, included dates in both the 1960s and 1980s (Table 1). Higher posterior probability support for candidate ages between 1984 and 1988 indicated ca. 24-28 years of weathering. However, our weathering calibration indicates that antlers would likely still have some preserved original bone textures after this weathering duration, or display weathering features more 
TABLE 1 | Antlers with conflicts between weathering features and most-supported ranges of post-bomb (BombNH13) calibrated AMS dates.

\begin{tabular}{lcll}
\hline Antler & $\begin{array}{c}\text { Original bone } \\
\text { texture } \\
\text { (Composite } \\
\text { Score) }\end{array}$ & $\begin{array}{l}\text { Calibrated date } \\
\text { range } \\
\text { (calendar } \\
\text { years) }\end{array}$ & $\begin{array}{l}\text { Posterior } \\
\text { probability }\end{array}$ \\
\hline T01-16-12 06 & 6 & $1959.14-$ & $27.1 \%$ \\
T01-42-15 78 & & 1961.75 & \\
& & $1984.08-$ & $67.8 \%$ \\
& & 1987.68 & $9.9 \%$ \\
& 6 & $1958.77-$ & $85.1 \%$ \\
& & 1984.13 & \\
& & $1988.64-$ &
\end{tabular}

Antler weathering is summarized by the Composite Score of original bone texture. Date ranges and associated posterior probability support is based on the $95 \%$ confidence interval of the calibration.

consistent with their recent loss. Thus, the highly weathered surfaces of T01-16-12 06 indicate it is an historical antler from ca. 1960. Antler T01-42-15 78 was collected in 2015 and has a similarly structured calibrated date showing support for either ca. 1960 or ca. 1986 (Table 1). However, T01-42-15 78 is more weathered than T01-16-12 06 (advanced form of Behrensmeyer's Weathering Stage 2; Behrensmeyer, 1978), including widening longitudinal cracks. Again, the highly weathered surfaces of T0142-15 78 are inconsistent with other antlers dating to the 1980 s and early 1990s (Figure 3). Thus, we determined T01-42-15 78 is an historical antler from the late 1950 s to early 1960 s.

Radiocarbon dates revealed that six antlers were shed prior to the 1900s. Each region of the Coastal Plain included at least one antler over 100 years old (Figure 4). Among these antlers, the oldest is ca. 700 years old (T03-02-11 28, Supplementary Tables 1, 2) and shows no indication of previous burial. Only one of the antlers with a calibrated date prior to the 1900s exhibited taphonomic indications of previous burial (T01-14-12 14, Supplementary Tables 1, 2).

\section{Antler ${ }^{87} \mathrm{Sr} /{ }^{86} \mathrm{Sr}$ Across Space and Time}

For both the Western and Central Coastal Plain, female antler ${ }^{87} \mathrm{Sr} /{ }^{86} \mathrm{Sr}$ (median and variance) differed significantly from bioavailable ${ }^{87} \mathrm{Sr} /{ }^{86} \mathrm{Sr}$ at the sites of antler collection (Figure 5, Table 2). For the Eastern Coastal Plain, antler and bioavailable ${ }^{87} \mathrm{Sr} /{ }^{86} \mathrm{Sr}$ had similar medians, but the variance of antler ${ }^{87} \mathrm{Sr} /{ }^{86} \mathrm{Sr}$ was significantly larger (Table 4). Overall, bioavailable ${ }^{87} \mathrm{Sr} /{ }^{86} \mathrm{Sr}$ increased across the study area from west to east (Figure 5). While antler ${ }^{87} \mathrm{Sr} /{ }^{86} \mathrm{Sr}$ also increased between the Western ( $n$ $=19)$ and Central Coastal Plain $(n=20 ; U=41, p<<0.01)$, there was no change in antler ${ }^{87} \mathrm{Sr} /{ }^{86} \mathrm{Sr}$ between the Central and Eastern Coastal Plain ( $n=20, U=173, p=0.85$; Figure 5).

Comparing recent female antlers among regions, we found that antler ${ }^{87} \mathrm{Sr} /{ }^{86} \mathrm{Sr}$ was indistinguishable between the Central and Eastern Coastal Plain (Porcupine Caribou calving grounds; Figure 6, Table 3A). However, antlers from both regions had significantly larger ${ }^{87} \mathrm{Sr} /{ }^{86} \mathrm{Sr}$ than the Western Coastal Plain (Central Arctic calving ground). This pattern was repeated for

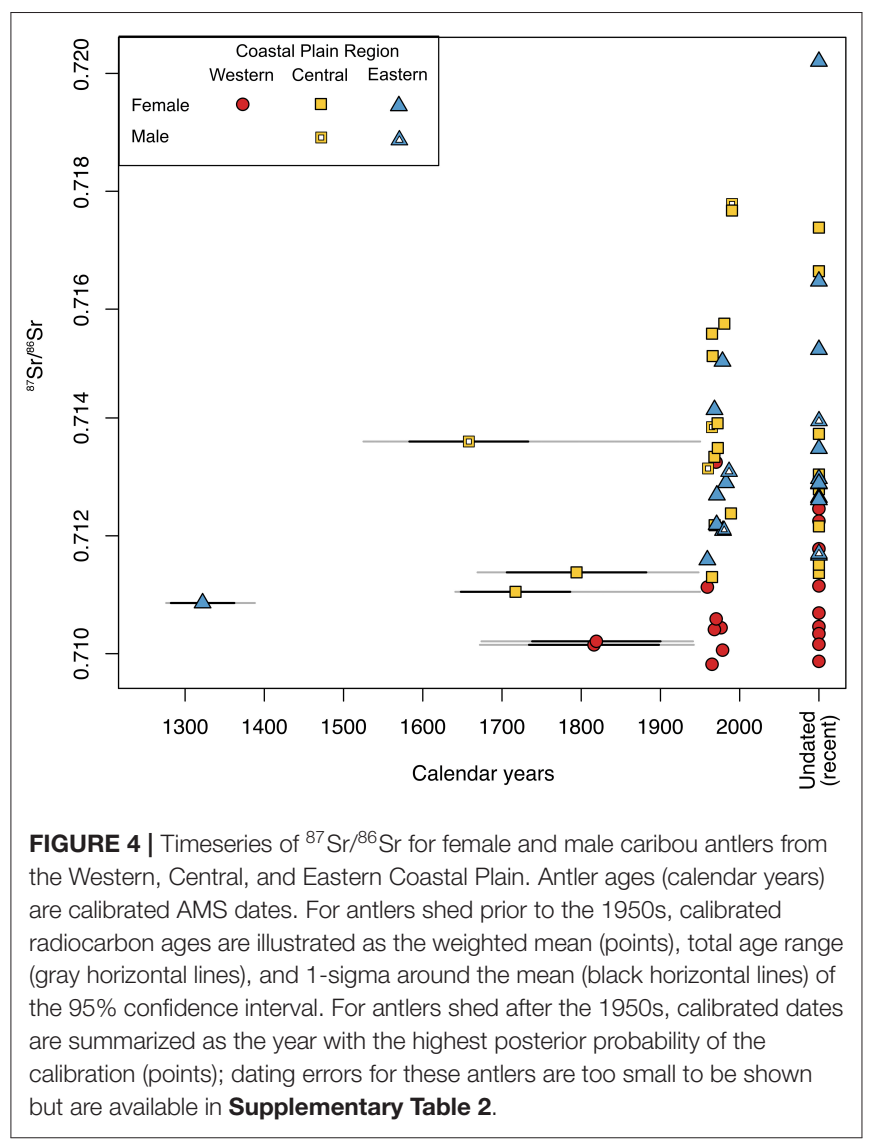

historical antlers; Central and Eastern Coastal Plain antlers were statistically indistinguishable, but Western Coastal Plain antlers had significantly smaller ${ }^{87} \mathrm{Sr} /{ }^{86} \mathrm{Sr}$ (Table 3B).

Comparing female antlers through time in each region, we found no differences between historical and recent antler ${ }^{87} \mathrm{Sr} /{ }^{86} \mathrm{Sr}$ in either the Central or Eastern Coastal Plain (Table 4). However, comparisons between historical and recent antlers from the Western Coastal Plain revealed multiple differences (Table 4). First, the distribution of ${ }^{87} \mathrm{Sr} /{ }^{86} \mathrm{Sr}$ for nearly all historical Western Coastal Plain antlers was more constrained than all other datasets (Figure 6). The one antler outside of this cluster (T01-18-12 05, grown ca. 1970; Supplementary Tables 1, 2) had a strontium isotope ratio more than six times the interquartile range larger than the median and was beyond the 95th percentile of the dataset, both satisfying common thresholds for identifying outliers (Gotelli and Ellison, 2004). Further, ${ }^{87} \mathrm{Sr} /{ }^{86} \mathrm{Sr}$ for this outlier exceeds that for any other antler from the Western Coastal Plain (historical or recent) and is close to the median for historical female antler ${ }^{87} \mathrm{Sr} /{ }^{86} \mathrm{Sr}$ for the Central Coastal Plain. Based on these characteristics, it is possible that this antler came from a rare Porcupine Herd female calving on the Western Coastal Plain. After removing this outlier, we find that recent antlers from the Western Coastal Plain have significantly larger variance and marginally larger ${ }^{87} \mathrm{Sr} /{ }^{86} \mathrm{Sr}$ compared to historical antlers (Table 4). Increased variance of recent antlers persists after the analysis is limited to 


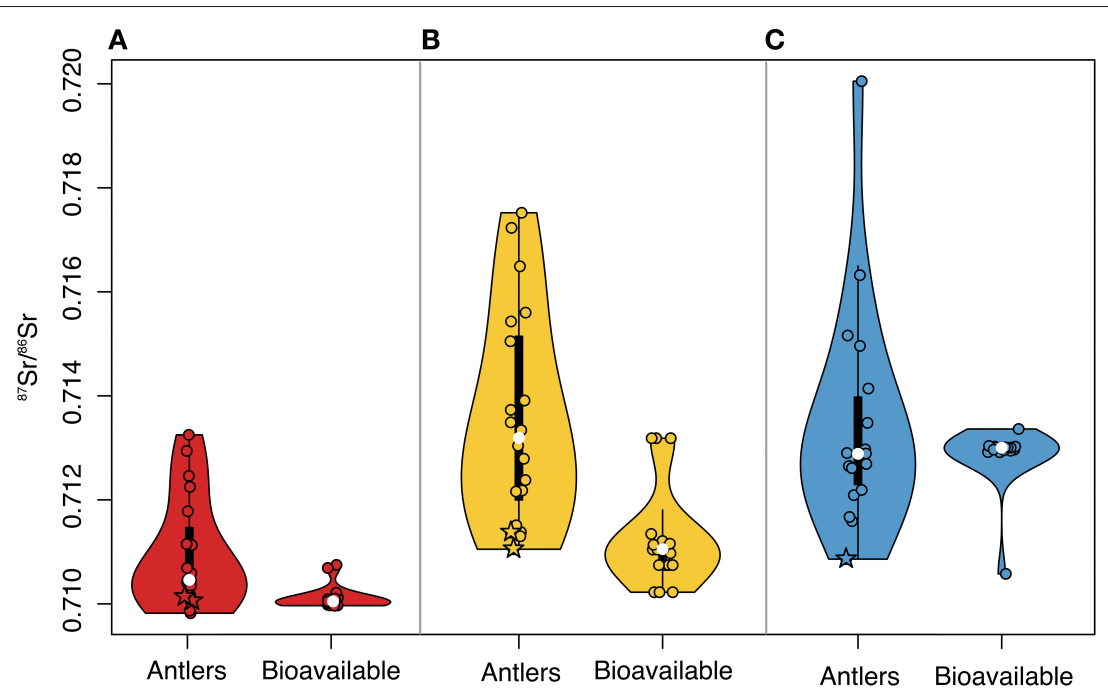

FIGURE 5 | Violin plots showing distributions of female antler ${ }^{87} \mathrm{Sr} /{ }^{86} \mathrm{Sr}$ and estimated bioavailable ${ }^{87} \mathrm{Sr} /{ }^{86} \mathrm{Sr}$ of each antler location for the (A) Western, (B) Central, and (C) Eastern Coastal Plain. Plots illustrate kernel density estimates (violin boundaries), interquartile range (thick vertical bars), 1.5 times the interquartile range (thin vertical line), and median (white point). Antler and bioavailable ${ }^{87} \mathrm{Sr} /{ }^{86} \mathrm{Sr}$ (points) are offset to aid visibility. Stars identify ${ }^{87} \mathrm{Sr} /{ }^{86} \mathrm{Sr}$ for antlers grown prior to $1900 \mathrm{CE}$.

TABLE 2 | Mann-Whitney $U$ and Levene tests between female antler ${ }^{87} \mathrm{Sr} /{ }^{86} \mathrm{Sr}$ and bioavailable ${ }^{87} \mathrm{Sr} /{ }^{86} \mathrm{Sr}$ at collection sites.

\begin{tabular}{|c|c|c|}
\hline Region ( $\mathbf{n}_{\text {antlers }}$ ) & Mann-Whitney U & Levene test \\
\hline Western (19) & $U=296, p<0.01$ & $10.42, p<0.01$ \\
\hline Central (20) & $U=362, p<<0.01$ & $11.54, p<0.01$ \\
\hline Eastern (18) & $U=126, p=0.26$ & $6.82, p=0.013$ \\
\hline
\end{tabular}

For each Coastal Plain region, sample size corresponds to the number of female antlers evaluated, which equals the number of estimated bioavailable ${ }^{87} \mathrm{Sr} / 86 \mathrm{Sr}$ values from the isoscape (Bataille et al., 2020). Significant comparisons are in bold.

antlers grown after $1900 \mathrm{CE}$, which approximately equalizes the temporal extents of the datasets (Table 4).

Differences between historical and recent antler ${ }^{87} \mathrm{Sr} /{ }^{86} \mathrm{Sr}$ from the Western Coastal Plain (Central Arctic Herd) correspond to shifts in modeled landscape use (Figures 7A,C). Modeled landscape use for recent antlers (Figure 7A) overlaps the documented summer range of the Central Arctic Herd (Figure 7A dashed line; Arthur and Del Vecchio, 2009; Nicholson et al., 2016). Strong correspondence between antler ${ }^{87} \mathrm{Sr} /{ }^{86} \mathrm{Sr}$ and biomonitoring records suggests the method is appropriate for extrapolating beyond known management conditions. Historical reconstructions show that regions of possible landscape use are more uniform (probabilities closer to 1.0 ) and concentrated within a smaller geographic region of the current summer range (Figure 7C). Data for historical antlers from the Central Arctic Herd also indicate that areas used today as calving grounds had previously been likely regions of summer range. We also found support for more focused historical use of the Arctic Refuge's 1002 Area during summer months (Figure 7C).
For the Porcupine Herd, modeled areas of potential landscape use (Figures 7B,D) are less focused than the Central Arctic Herd; a pattern that holds for both historical and recent periods. Modeled landscape use based on recent antlers overlaps the documented summer range of the Porcupine Herd (Figure 7B, dashed line), though probability surfaces also show support outside of the Porcupine Herd's summer range.

Antlers from the Central and Eastern Coastal Plain that were grown prior to $1900 \mathrm{CE}$ ("antique" antlers) generally have small ${ }^{87} \mathrm{Sr} /{ }^{86} \mathrm{Sr}$, and in some cases the smallest ${ }^{87} \mathrm{Sr} /{ }^{86} \mathrm{Sr}$ for their respective regions (Figure 4). This is not universal, however, as the oldest Western Coastal Plain antlers do not have unusually small ${ }^{87} \mathrm{Sr} /{ }^{86} \mathrm{Sr}$ compared to historical antlers younger than 1900 CE (Figure 4). Further, the single antique male antler from the Central Coastal Plain (Figure 4, open square, ${ }^{87} \mathrm{Sr} /{ }^{86} \mathrm{Sr}=$ 0.71360 ) has larger ${ }^{87} \mathrm{Sr} /{ }^{86} \mathrm{Sr}$ than antique females from the same region (mean female antique $^{87} \mathrm{Sr} /{ }^{86} \mathrm{Sr}=0.71122$ ) but is consistent with the mean for Central Coastal Plain historical antlers grown after $1900 \mathrm{CE}$ (male-only $=0.71349$, female + male $=0.71373$; female-only $=0.71379)$. Thus, ${ }^{87} \mathrm{Sr} /{ }^{86} \mathrm{Sr}$ is not explicitly linked to time.

Male and female antlers from the Central and Eastern Coastal Plain show broad overlap in ${ }^{87} \mathrm{Sr} /{ }^{86} \mathrm{Sr}$ (Figure 4). After pooling all female $(n=38)$ and male antlers $(n=7)$, we do not find evidence for isotopic distinction between sexes $(U=117, p=0.63)$.

\section{DISCUSSION}

\section{Expanding Ecological Timeseries}

Our results demonstrate that antlers on the Arctic Refuge Coastal Plain can predate management records by centuries. Because slow weathering processes enable long-term survival of bone 


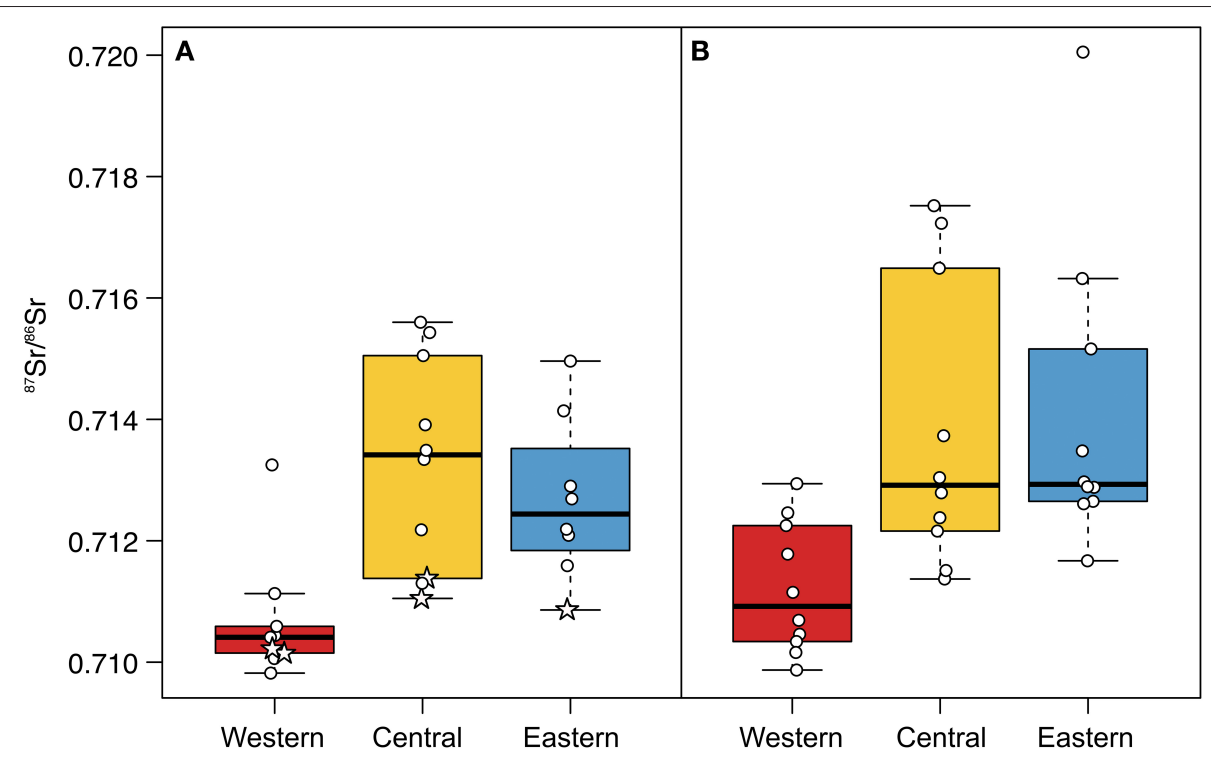

FIGURE 6 | Distributions of ${ }^{87} \mathrm{Sr} /{ }^{86} \mathrm{Sr}$ for (A) historical and (B) recent female antlers from the Western, Central, and Eastern Coastal Plain. Stars identify ${ }^{87} \mathrm{Sr} /{ }^{86} \mathrm{Sr}$ for antlers grown prior to $1900 \mathrm{CE}$. Boxplots illustrate the interquartile range (box), 1.5 times the interquartile range (dashed whiskers), and median (thick black bar). Points (female antler ${ }^{87} \mathrm{Sr} /{ }^{86} \mathrm{Sr}$ ) are offset to aid visibility.

TABLE 3 | Pairwise Mann-Whitney $U$-tests among female antler ${ }^{87} \mathrm{Sr} /{ }^{86} \mathrm{Sr}$ in the Western, Central, and Eastern Coastal Plain.

Central Eastern

\begin{tabular}{lll}
\hline $\begin{array}{l}\text { A. Recent antlers } \\
\text { Western }\end{array}$ & $\boldsymbol{U}=\mathbf{1 4 ,} \boldsymbol{p}=\mathbf{0 . 0 1 6}$ & $\boldsymbol{U}=\mathbf{8}, \boldsymbol{p}=\mathbf{0 . 0 0 2 2}$ \\
Eastern & $U=55, p>0.05$ & \\
B. Historical antlers & \\
Western & $\boldsymbol{U}=\mathbf{5}, \boldsymbol{p}=\mathbf{0 . 0 0 1 2}$ & $\boldsymbol{U}=\mathbf{7}, \boldsymbol{p}=\mathbf{0 . 0 1 1}$ \\
Eastern & $U=32, p>0.05$ &
\end{tabular}

Separate tests are provided for comparisons among $(\boldsymbol{A})$ recent antlers and $(\boldsymbol{B})$ historical antlers. Sample sizes for recent antlers are Western (10), Central (10), Eastern (10). Sample sizes for historical antlers are Western (9), Central (10), Eastern (8). To maintain an alpha value of 0.05 , all $p$-values were multiplied by 3 to correct for the number of comparisons. Significant results are in bold.

TABLE 4 | Mann-Whitney $U$ and Levene tests between historical and recent female antlers from the Western, Central, and Eastern Coastal Plain.

\begin{tabular}{|c|c|c|}
\hline Region ( $n_{\text {Historical }}, n_{\text {Recent }}$ ) & Mann-Whitney U & Levene test \\
\hline Western $(8,10)$ & $U=19, p=0.068 \bullet$ & $7.63, p=0.014$ \\
\hline Western $_{1900 s-2000 s}(6,10)$ & $U=16, p=0.15$ & $5.26, p=0.038$ \\
\hline Central $(10,10)$ & $U=44, p=0.68$ & $0.82, p=0.38$ \\
\hline Eastern $(8,10)$ & $U=24, p=0.17$ & $0.95, p=0.34$ \\
\hline
\end{tabular}

Comparisons among Western Coastal Plain antlers are calculated with the outlier removal. Western Coastal Plain antlers grown after 1900 are compared in Western 1900 s-2000s. Significant results are in bold. Marginally significant comparison $(p<0.1)$ indicated as - $n_{\text {Historical }}=$ sample size of historical antlers. $n_{\text {Recent }}=$ sample size of recent antlers.

(Meldgaard, 1986; Sutcliffe and Blake, 2000), antlers lying on tundra surfaces can dramatically extend the temporal window with which we assess caribou landscape use. The simple presence of shed female antlers from hundreds of years ago lying on the same landscapes as antlers of caribou that recently gave birth provides the first physical evidence of the longstanding use of the Arctic Refuge Coastal Plain as a calving ground. This finding is consistent with accounts of caribou herd behaviors in the $1800 \mathrm{~s}$ and traditional ecological knowledge of the Gwich'in (Burch, 2012; Benson, 2019). Furthermore, because antlers are still being deposited on arctic landscapes, antler surveys simultaneously yield data on contemporary and distantly historical populations, contributing unique data for evaluating ecological responses to long-term environmental changes (Mihoub at al., 2017) for a highly mobile and long-lived mammal at increasing risk due to climate change and anthropogenic disturbance (Festa-Bianchet et al., 2011; Tucker et al., 2018).

Slow bone weathering on the Coastal Plain is likely caused by multiple factors, with below-freezing mean annual temperatures likely being of central importance (Fiorillo, 1995; Douglas et al., 2002; Todisco and Monchot, 2008; Miller, 2011; Pokines et al., 2016). Additionally, while summers bring 24-h sun and prolonged exposure to ultraviolet (UV) radiation, UV intensity is low at arctic latitudes and Coastal Plain summers are often cloudy or blanketed in dense fog for weeks at a time (U.S. Fish Wildlife Service, 2015; Miller, personal obs.). Bone weathering rates may also be slowed through limited summer rainfall, and reduced wet-dry cycles (shrinkage-expansion) that damage bone, particularly on well-drained Dryas terraces (Behrensmeyer, 1978; U.S. Fish Wildlife Service, 2015; Pokines et al., 2018). Under such conditions, it is perhaps unsurprising that antlers are well-preserved for extended durations, including maintaining original bone texture for decades. Similar or more extreme conditions in the Canadian High Arctic and Greenland support the persistence of unburied antlers on landscape surfaces for 
millennia (Meldgaard, 1986; Sutcliffe and Blake, 2000). This is in stark contrast to tropical settings, where bones of large mammals are unlikely to persist beyond several decades (Behrensmeyer, 1978; Tappen, 1994), or temperate settings where bones may only survive on landscape surfaces for up to two centuries (Miller, 2011). The need for historical references is particularly acute in arctic populations, as these ecosystems have already been and will continue to be subjected to some of the most extreme environmental perturbations due to global warming (ACIA, 2004; Graversen et al., 2008; IPCC, 2014). Unfortunately, data access and integration from arctic ecosystems are often hampered by challenges in consistently accessing remote areas as well as changes in survey methodologies (but see Magurran et al., 2010). Even under such constraints, bones, teeth, and antlers lying on landscape surfaces can faithfully record diverse aspects of community ecology and seasonal landscape use and allow us to reclaim components of lost ecological history (Behrensmeyer et al., 1979; Western and Behrensmeyer, 2009; Miller, 2011, 2012; Miller et al., 2013, 2014).

\section{Antler ${ }^{87} \mathrm{Sr} /{ }^{86} \mathrm{Sr}$ vs. Bioavailable ${ }^{87} \mathrm{Sr} /{ }^{86} \mathrm{Sr}$}

Mismatch between female antler ${ }^{87} \mathrm{Sr} /{ }^{86} \mathrm{Sr}$ and bioavailable ${ }^{87} \mathrm{Sr} /{ }^{86} \mathrm{Sr}$ across the Coastal Plain indicated that antlers were not grown locally (Figure 5, Table 2). As both herds are migratory, this was an expected finding and is consistent with previous work showing that differences between skeletal materials and local bioavailable ${ }^{87} \mathrm{Sr} /{ }^{86} \mathrm{Sr}$ can identify mobile individuals (e.g., Hoppe et al., 1999; Hoppe and Koch, 2007; Baumann and Crowley, 2015). We also showed that broad spatial sampling (here, across $100 \mathrm{~km}$ ) and evaluating multiple summary statistics (e.g., median and variance) can be important for evaluating differences between focal specimens and regional changes in bioavailable ${ }^{87} \mathrm{Sr} /{ }^{86} \mathrm{Sr}$. For example, median values of antler and bioavailable ${ }^{87} \mathrm{Sr} /{ }^{86} \mathrm{Sr}$ on the Eastern Coastal Plain were not statistically different, though antler ${ }^{87} \mathrm{Sr} /{ }^{86} \mathrm{Sr}$ had larger variance (Figure 5, Table 2). Antler ${ }^{87} \mathrm{Sr} /{ }^{86} \mathrm{Sr}$ also did not follow the westto-east gradient of increasing bioavailable ${ }^{87} \mathrm{Sr} /{ }^{86} \mathrm{Sr}$ across the study area, further indicating antlers were not grown where they were shed.

\section{Antler ${ }^{87} \mathrm{Sr} /{ }^{86} \mathrm{Sr}$ Can Differentiate Caribou Populations}

Shed female antlers track two components of seasonal landscape use: ranges used during antler growth (antler ${ }^{87} \mathrm{Sr} /{ }^{86} \mathrm{Sr}$ ) and the subsequent spring calving ground (shed antler locations). Herd-specific patterns of landscape use by the Central Arctic Herd (Western Coastal Plain) and Porcupine Herd (Central and Eastern Coastal Plain) can be differentiated using ${ }^{87} \mathrm{Sr} /{ }^{86} \mathrm{Sr}$ of female antlers lying on tundra surfaces. When multiple herds are contributing antlers to a region, differentiating herd-specific inputs is an important step before using spatial variability in antler densities (antlers $/ \mathrm{km}^{2}$ ) to evaluate preferences in landscape use (Miller and Barry, 1992; Miller, 2012; Miller et al., 2013). While the discriminatory power of this method relies on the variability and distinctiveness of bioavailable ${ }^{87} \mathrm{Sr} /{ }^{86} \mathrm{Sr}$ among herd ranges (Beard and Johnson, 2000; Britton et al., 2011; Crowley et al., 2017), differences in ${ }^{87} \mathrm{Sr} /{ }^{86} \mathrm{Sr}$ between antlers on
Central Arctic and Porcupine Herd calving grounds indicate that even herds with partially overlapping ranges (Figure 1) can be distinguished when geologic conditions are favorable.

\section{Landscape Use Through Time: The Porcupine Caribou Herd}

Antler ${ }^{87} \mathrm{Sr} /{ }^{86} \mathrm{Sr}$ indicates that for caribou calving on the Central and Eastern Coastal Plain, overall patterns of landscape use during the previous summer have been consistent since at least the 1960s (Figures 6, 7). These data augment biomonitoring records that also suggest large-scale continuity in seasonal calving and summer ranges (Russell et al., 1993; Griffith et al., 2002; McFarland et al., 2017).

Herd size is an important contributor to changes in caribou landscape use, including shifts in the fidelity of seasonal ranges, migratory distances, and the tendency of individuals to migrate or remain more sedentary (Skoog, 1968; Fancy et al., 1989; Schaefer and Mahoney, 2003, 2013; Hinkes et al., 2005; Couturier et al., 2010; Taillon et al., 2012; Peters et al., 2017; Joly et al., 2019). Climate cycles such as the Pacific Decadal Oscillation and the North Atlantic Oscillation can also influence landscape ecology and population size (Griffith et al., 2002; Joly et al., 2011). Yet, even amidst changes in climate and herd size, we find continuity between shed Porcupine Herd antler locations (calving grounds) and their antler geochemistry (summer landscape use). An important component of this consistency may be the relatively small extent of anthropogenic development across the Porcupine Herd range, permitting populations to fluidly adapt their landscape use to changes in climate and population size. Expanded sampling of antler ${ }^{87} \mathrm{Sr} /{ }^{86} \mathrm{Sr}$ from calving areas in the Arctic Refuge and neighboring Yukon will provide important tests for how ubiquitous this stability is between summer and calving ranges. If infrastructural development increases in Porcupine Herd ranges, it will be important to track the degree to which the links between calving grounds and summering areas stay within the range of multidecadal variability established here.

While antler ${ }^{87} \mathrm{Sr} /{ }^{86} \mathrm{Sr}$ for the Central and Eastern Coastal Plain portrays a degree of ecological consistency across relatively recent history, antique antlers (grown prior to $1900 \mathrm{CE}$ ) from this region have comparatively small ${ }^{87} \mathrm{Sr} /{ }^{86} \mathrm{Sr}$ (Figures 4, 6 stars). Our small datasets preclude a full evaluation, but there are two potential reasons why antique Central and Eastern Coastal Plain antlers could have small ${ }^{87} \mathrm{Sr} /{ }^{86} \mathrm{Sr}$ : (1) diagenetic alternation, or (2) different patterns of landscape use during the Little Ice Age (1250 to as late as $1900 \mathrm{CE}$; Solomina et al., 2015; Gaglioti et al., 2019).

Overall excellent preservation of antlers suggests that subtle differences in antique antler ${ }^{87} \mathrm{Sr} /{ }^{86} \mathrm{Sr}$ of the Central and Eastern Coastal Plain most likely reflect changes in landscape use. Antlers have generally undergone limited taphonomic modification, the most obvious of which includes gnawing, UV-exposure, freeze-thaw, and root etching (one buried specimen). Cutting the specimens for AMS dating also revealed that weathering features are generally limited to a thin patina near the surface without penetrating deeply into the antler. Consistent with 


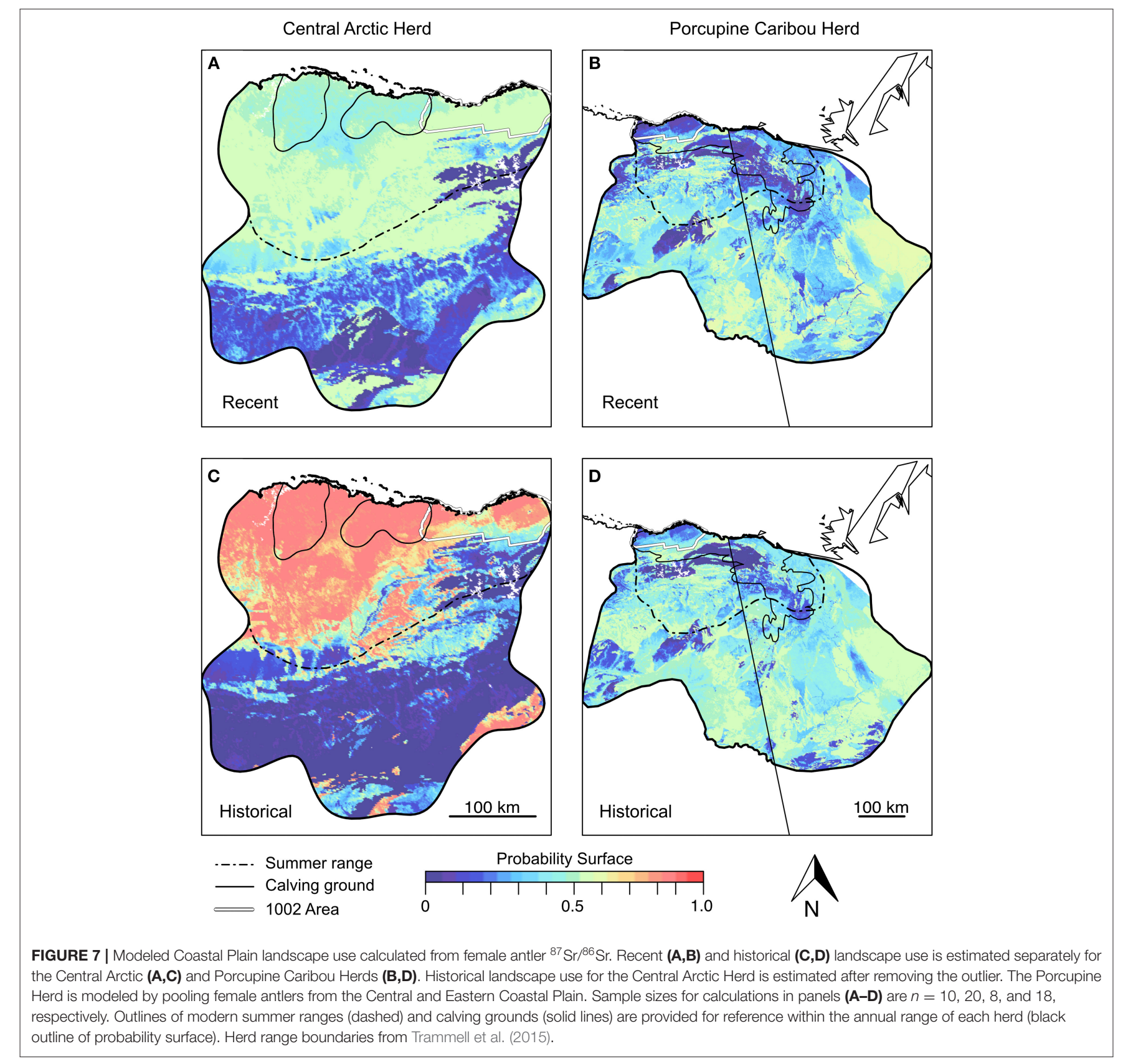

well-preserved bone, antlers do not show steady shifts in ${ }^{87} \mathrm{Sr} /{ }^{86} \mathrm{Sr}$ with time, which would be expected for early diagenetic obfuscation of primary isotope values. For example, after over 50 years of weathering, there is no change in median ${ }^{87} \mathrm{Sr} /{ }^{86} \mathrm{Sr}$ between recent and historical antlers on the Central and Eastern Coastal Plain (Figure 6). If alteration was driving antique antler ${ }^{87} \mathrm{Sr} /{ }^{86} \mathrm{Sr}$, we would also expect to see similar values for similarly aged antlers. Instead, similarly-aged antique antlers from the Central Coastal Plain have highly variable ${ }^{87} \mathrm{Sr} /{ }^{86} \mathrm{Sr}$ (Figure 4, yellow squares). Additionally, ${ }^{87} \mathrm{Sr} /{ }^{86} \mathrm{Sr}$ for the oldest Eastern Coastal Plain antler (T03-02-11 28; Figure 5C), is smaller than bioavailable ${ }^{87} \mathrm{Sr} /{ }^{86} \mathrm{Sr}$. Thus, even after hundreds of years of weathering, we do not see strong evidence that antique antler ${ }^{87} \mathrm{Sr} /{ }^{86} \mathrm{Sr}$ was altered. Strontium ratios of antique antlers from the Western Coastal Plain (Central Arctic Herd, discussed more below) are also not abnormally small relative to more recently shed antlers in that region (Figures 4, 6). In the absence of a clear diagenetic explanation, the alternative explanation is that smaller ${ }^{87} \mathrm{Sr} /{ }^{86} \mathrm{Sr}$ of antique female antlers from the Central and Eastern Coastal Plain reflect a shift in summer landscape use for caribou calving in these regions during the Little Ice Age. Robustly evaluating this hypothesis will require larger sample sizes of antique antlers, but our results provide a first glimpse into possible differences in caribou landscape use during a time 
when northeastern Alaska was significantly cooler and perhaps drier (Sikorski et al., 2009).

\section{Landscape Use Through Time: The Central Arctic Herd}

The Western Coastal Plain offers an excellent opportunity to sample antlers from Central Arctic Herd calving grounds while minimizing the distance to Porcupine Herd calving grounds. This close proximity makes comparing Western Coastal Plain antlers with antlers from the Central and Eastern Coastal Plain a strong test of whether antler ${ }^{87} \mathrm{Sr} /{ }^{86} \mathrm{Sr}$ can differentiate herd identity. At the same time, because the Western Coastal Plain is only one edge of the Central Arctic Herd calving grounds, sampling antler ${ }^{87} \mathrm{Sr} /{ }^{86} \mathrm{Sr}$ across the remainder of their calving grounds will be important for assessing the full scope of changes in summer landscape use through time.

For antlers collected along the Western Coastal Plain, those shed in the 1980s and more recently show a shift in median ${ }^{87} \mathrm{Sr} /{ }^{86} \mathrm{Sr}$ and greater variability than historical antlers. These changes manifest as greater overlap in recent ${ }^{87} \mathrm{Sr} /{ }^{86} \mathrm{Sr}$ between Western Coastal Plain antlers $(n=4$ of 10$)$ and those of the Central and Eastern Coastal Plain (Figure 6). There are two plausible explanations for these changes: (1) increased calving by the Porcupine Herd on the Western Coastal Plain; and (2) shifts in landscape use by the Central Arctic Herd.

The first possibility seems unlikely because the Porcupine Herd rarely calve near the Western Coastal Plain and there is no spatial overlap between our antler surveys and known Porcupine Herd calving areas. While the Porcupine Herd calved nearest our antler surveys in the early 1990s (Griffith et al., 2002; McFarland et al., 2017), antlers from this time-period are not well-represented in our dataset. Antlers were surveyed on the Western Coastal Plain in 2012, so antlers shed in the mid-1990s would mostly likely have original bone texture with Composite Scores of 3 or 4 (Figure 3). Instead, the majority of recent antlers from the Western Coastal Plain $(n=6$ of 10) are nearly pristine (Composite Score 0 ), including half the Western Coastal Plain ${ }^{87} \mathrm{Sr} /{ }^{86} \mathrm{Sr}$ values (2 of 4 ) that overlap recent Central and Eastern Coastal Plain antlers. While Composite Score 0 has not been calibrated to weathering duration, comparisons to bone weathering observed elsewhere (Miller, 2011) suggest that these antlers were likely shed in the preceding decade. Thus, it is unlikely that the shift in Western Coastal Plain antler ${ }^{87} \mathrm{Sr} /{ }^{86} \mathrm{Sr}$ between historical and recent times was driven by antlers from Porcupine Herd females.

We consider the second possibility as the most probable scenario: differences in historical and recent antler ${ }^{87} \mathrm{Sr} /{ }^{86} \mathrm{Sr}$ from the Western Coastal Plain are best explained as a shift in summer landscape use by the Central Arctic Herd after the 1970s. Comparisons of modeled recent and historical summer landscape use (Figures 7A,C) indicate that range shifts were nontrivial. Historical summer landscape use (Figure 7C) was more consistent among individuals (probabilities closer to 1.0) with increased summer activity in what is currently spring calving grounds of the Central Arctic Herd. Reconstructions also indicate more concentrated summer use in the northeast and northwest portions of the Arctic Refuge's 1002 Area. While our dataset does not have the temporal resolution to pinpoint the onset of changes, the observed isotopic shifts roughly coincide with three factors known to alter patterns of landscape use in caribou: (1) population growth, (2) climate change, and (3) increased anthropogenic disturbances to their summer and calving ranges.

Since modern biomonitoring surveys were initiated in the 1970s, the Central Arctic Herd experienced some of the largest proportional population swings of any of Alaska's northern caribou herds, including an over 10-fold increase in population size between 1978 and 2010 (Cameron et al., 2005; Lenart, 2015). Most "recent" antlers come from this period of dramatic population increase, though some minimally weathered antlers (Composite Score 0) may come from the initial period of population reduction following 2010. It is possible that increased variance of ${ }^{87} \mathrm{Sr} /{ }^{86} \mathrm{Sr}$ in recent antlers and the marginal shift toward larger ${ }^{87} \mathrm{Sr} /{ }^{86} \mathrm{Sr}$ (Table 4) is a reflection of changes in landscape use associated with population expansion (Boertje and Gardner, 2000; Bergerud et al., 2008; Nicholson et al., 2016). However, similarity in antler ${ }^{87} \mathrm{Sr} /{ }^{86} \mathrm{Sr}$ across the historical antler timeseries is intriguing as it includes two antlers from the 1800s that may also have come from larger populations. Knowledge of caribou populations from this time are limited, but reports from travelers in northeast Alaska indicate that the historical equivalent of the Central Arctic Herd had population highs ca. 1840 and between the 1880s and 1890s (Burch, 2012). Uncertainties in calibrated AMS dates are high for the two antique antlers (T01-14-12 14, T01-16-12 10), but the most supported date ranges overlap these periods of past population highs (1832-1893 and 1833-1891, respectively; Supplementary Table 2). Thus, through time, relationships between antler ${ }^{87} \mathrm{Sr} /{ }^{86} \mathrm{Sr}$ and herd size may be complex and should be explored with a more complete timeseries.

Environmental and ecological changes due to global climate change are particularly acute in the arctic, where surface temperature anomalies have been consistently increasing since the 1980s or earlier (ACIA, 2004; Graversen et al., 2008; IPCC, 2014). Climate can influence ungulate population size and landscape ecology (Post and Stenseth, 1998; Joly et al., 2011) and is an obvious candidate driver of recent shifts in Central Arctic Herd antler ${ }^{87} \mathrm{Sr} /{ }^{86} \mathrm{Sr}$. However, antler ${ }^{87} \mathrm{Sr} /{ }^{86} \mathrm{Sr}$ of the Porcupine Herd showed no response across the same interval, even though landscapes of the Arctic Coastal Plain and the Porcupine Herd itself are known to respond strongly to climate and environmental change (Griffith et al., 2002; Joly et al., 2011). While testing the role of climate in structuring recent shifts in Central Arctic Herd landscape use requires further exploration, the lack of response by the Porcupine Herd to recent warming is noteworthy and suggests other factors may be contributing to the shift in Central Arctic Herd landscape use.

Increased human developments during the 1970s and 1980s are a likely alternative driver of shifts in summer landscape use for the Central Arctic Herd. Infrastructural development supporting oil exploration and recovery has been occurring in Central Arctic Herd ranges since the 1960s. However, the scale and scope of development increased in the mid 1970s and 1980s, including oil field expansion, construction of the 
Trans-Alaska Pipeline, and road networks built through portions of the Central Arctic Herd's calving, summer, and winter ranges (Fancy, 1983; Arthur and Del Vecchio, 2009; Nicholson et al., 2016). There are known behavioral responses to infrastructure, including avoidance of pipelines and roads by pregnant females and reduced calf birth weight in areas with more intense anthropogenic impacts and barriers (Cameron and Whitten, 1980; Cameron et al., 2002, 2005; Arthur and Del Vecchio, 2009; Nicholson et al., 2016). Multiple anthropogenic disturbances to movement and habitat access can also compound into regional-scale impacts on caribou landscape use (Johnson and Russell, 2014; Johnson et al., 2020). Thus, a shift between historical and recent Central Arctic Herd summer range is not surprising. An important future area of research will be to test this shift in preferred summer landscapes using an expanded sampling of antlers across the herd's calving grounds. Of particular interest is to compare modeled summer landscape use between the two epicenters of Central Arctic Herd calving (Figure 1). If anthropogenic pressures are driving changes in summer landscape use of the Central Arctic Herd, one would expect greater differences between historical and recent shifts for caribou calving within the western calving ground, which has undergone more intense development. Antler data could also test the longevity of the two calving centers, and if calving was more geographically continuous prior to major development projects. A combined approach linking Traditional Ecological Knowledge of caribou with antler proxy studies could be a valuable strategy for synthesizing available information on historical patterns of seasonal landscape use.

\section{Future Directions for Modeling Bioavailable ${ }^{87} \mathrm{Sr} /{ }^{86} \mathrm{Sr}$}

When working across the spatial scales of caribou ranges, translating changes in antler ${ }^{87} \mathrm{Sr} /{ }^{86} \mathrm{Sr}$ through time into estimated shifts in landscape use requires a modeled ${ }^{87} \mathrm{Sr} /{ }^{86} \mathrm{Sr}$ isoscape. An important assumption in using such a model is that caribou diet echoes local bioavailable ${ }^{87} \mathrm{Sr} /{ }^{86} \mathrm{Sr}$ (as defined by exchangeable ${ }^{87} \mathrm{Sr} /{ }^{86} \mathrm{Sr}$ in soils that are incorporated into local plants). While this is a reasonable assumption for most consumers, caribou are somewhat unusual in their consumption of lichens, which incorporate the bulk of their nutrients from atmospheric sources (Nash, 2008). Consequently, caribou ${ }^{87} \mathrm{Sr} /{ }^{86} \mathrm{Sr}$ may be influenced by atmospherically available ${ }^{87} \mathrm{Sr} /{ }^{86} \mathrm{Sr}$ more than many mammals. However, while caribou consume large amounts of lichens during fall and winter, summer diets (coincident with the bulk of antler growth) are dominated by herbaceous browse that more likely reflects modeled bioavailable ${ }^{87} \mathrm{Sr} /{ }^{86} \mathrm{Sr}$ (Thompson and McCourt, 1981; Boertje, 1984). Another possible caveat is that while the model used to estimate bioavailable ${ }^{87} \mathrm{Sr} /{ }^{86} \mathrm{Sr}$ includes soil and plant data from Alaska, it does not incorporate samples from our exact study area. We do not think this is a large issue. The isoscape, which is intended for global applications, is generally accurate even in regions distant from directly sampled points, and this is particularly true for North America and Europe (Bataille et al., 2020). Nevertheless, future work will focus on sampling plants, soils, lichens, and small mammals from the Coastal Plain to develop a more nuanced ${ }^{87} \mathrm{Sr} /{ }^{86} \mathrm{Sr}$ isoscape for the Arctic Refuge and surrounding regions.

\section{Place-Based Baselines of Ecological Variability From Bones on the Landscape}

Today, naturally continuous landscapes are divided by invisible boundaries controlled by different countries, government entities, and private landowners, each with differing management mandates and stakeholder interests. Because of these divisions, many conservation and management questions focus on specific regions. The Arctic Refuge is no exception, where the 1002 Area is the focus of many management questions and ecological studies (Cameron and Whitten, 1980; Cameron et al., 1992, 2005; Arthur and Del Vecchio, 2009; Pearce et al., 2018; Russell and Gunn, 2019). Yet, particularly for highly mobile species, it can be challenging to discriminate the ecological "value" of one area relative to another, or the overall breadth of habitats and geographies needed to maintain a population or species. Bone surveys provide data that are inherently local. For caribou and other highly mobile taxa, bone geochemistry may also identify regions of additional ecological significance. Perhaps most importantly, beyond a snapshot of current ecological conditions, surveys of skeletal materials can establish biological variability through time and highlight when populations and communities have shifted beyond decadal-, centennial-, or even millennialscale baselines (Terry, 2009; Rowe and Terry, 2014; Kidwell, 2015; Tomasovych and Kidwell, 2017). Slow bone weathering rates in Arctic settings may produce particularly time-rich datasets, but bones and their spatiotemporal records are ubiquitous in a wide variety of climatic settings and habitats (Behrensmeyer et al., 1979; Tappen, 1995; Andrews and Armour-Chelu, 1998; Andrews and Whybrow, 2005; Western and Behrensmeyer, 2009; Miller, 2011). Where gaps in historical ecological knowledge persist, those landscapes may be covered in skeletal data that are both spatially explicit and time-rich.

\section{CONCLUSIONS}

Accumulations of shed caribou antlers lying on calving grounds of the Arctic National Wildlife Refuge, Alaska, provide data on seasonal landscape use that complement more traditional wildlife surveys. Shed female antlers also extend our records of seasonal landscape use and caribou activity on Arctic Refuge calving grounds by over 700 years. Our findings support that antler ${ }^{87} \mathrm{Sr} /{ }^{86} \mathrm{Sr}$ can discriminate caribou herds and establish historical contexts for modern patterns of seasonal landscape use. Female antler ${ }^{87} \mathrm{Sr} /{ }^{86} \mathrm{Sr}$ from the Arctic Refuge's Central and Eastern Coastal Plain (a calving ground of the Porcupine Herd) has been consistent since the 1960s, indicating continuity in patterns of summer landscape use (when females grow antlers). Conversely, antler ${ }^{87} \mathrm{Sr} /{ }^{86} \mathrm{Sr}$ from the Western Coastal Plain (a calving ground of the Central Arctic Herd) reveals meaningful shifts in caribou landscape use after the 1970s, a time of significant changes in herd size, climate, and infrastructural development within the herd's calving and summer ranges. The decadal-to-centennial-scale 
perspectives provided by accumulations of shed antlers and their isotope geochemistry provide important baselines for evaluating variability in caribou migration and landscape use prior to the initiation of traditional biomonitoring efforts. The longterm perspectives available from antlers are likely ubiquitous on arctic caribou calving grounds and can be acquired from relatively limited sampling. Emerging toolkits for decoding the records preserved in accumulations of antlers and other bones are producing historical ecological data that were once considered lost to time.

\section{DATA AVAILABILITY STATEMENT}

The original contributions presented in the study are included in the Supplementary Materials. Further inquiries can be directed to the corresponding author.

\section{ETHICS STATEMENT}

Ethical review and approval was not required for this study because no living animals were used.

\section{AUTHOR CONTRIBUTIONS}

JM designed the project, conducted fieldwork, analyzed data, and wrote the manuscript. $\mathrm{BC}$ and $\mathrm{AK}$ prepared specimens for isotope analysis. $\mathrm{CB}$ analyzed the combined surface probabilities. EW conducted fieldwork. MG wrote part of the manuscript. VB

\section{REFERENCES}

ACIA (Arctic Climate Impact Assessment). (2004). Impacts of a Warming Arctic: Arctic Climate Impact Assessment. New York, NY: Cambridge University Press.

Andrews, P. (1995). Experiments in taphonomy. J. Archaeol. Sci. 22, 147-153. doi: 10.1006/jasc.1995.0016

Andrews, P., and Armour-Chelu, M. (1998). Taphonomic observations on a surface bone assemblage in a temperate environment. Bull. Soc. Géologique France 169, 433-442.

Andrews, P., and Whybrow, P. (2005). Taphonomic observations on a camel skeleton in a desert environment in Abu Dhabi. Palaeontol. Electron. 8, 1-17.

Arthur, S. M., and Del Vecchio, P. A. (2009). Effects of oil field development on calf production and survival in the Central Arctic herd. Alaska Department of Fish and Game, Final Research Technical Report. Grants W-27-5 and W-33-1 through W-33-4. Project 3.46. Juneau, AK: Federal Aid in Wildlife Restoration.

Avgar, T., Street, G., and Fryxell, J. M. (2014). On the adaptive benefits of mammal migration. Can. J. Zool. 92, 481-490. doi: 10.1139/cjz-2013-0076

Baltensperger, A. P., and Joly, K. (2019). Using seasonal landscape models to predict space use and migratory patterns of an arctic ungulate. Movement Ecol. 7:18. doi: 10.1186/s40462-019-0162-8

Barnosky, A. D., Hadly, E. A., Gonzalez, P., Head, J., Polly, P. D., Lawing, A. M., et al. (2017). Merging paleobiology with conservation biology to guide the future of terrestrial ecosystems. Science 355:eaah4787. doi: 10.1126/science.aah4787

Bataille, C. P., Crowley, B. E., Wooller, M. J., and Bowen, G. J. (2020). Advances in global bioavailable strontium isoscapes. Palaeogeogr. Palaeoclimatol. Palaeoecol. 555:109849. doi: 10.1016/j.palaeo.2020.109849

Bataille, C. P., von Holstein, I. C. C., Laffoon, J. E., Willmes, M., Liu, X.-M., and Davies, G. R. (2018). A bioavailable strontium isoscape for Western Europe: a machine learning approach. PLoS ONE 13:e0197386. doi: 10.1371/journal.pone.0197386 contributed to the analytical framework. PD provided logistical and field support in Alaska. All authors contributed to and edited the manuscript.

\section{FUNDING}

This research was supported by the U.S. Fish and Wildlife Service (Arctic National Wildlife Refuge), the National Geographic Society (grant 9133-12 to JM), a Christine Stevens Wildlife Award from the Wildlife Society (to JM), and the University of Cincinnati.

\section{ACKNOWLEDGMENTS}

We are grateful to the many people who helped make this work possible, including Dave Payer, Steve Arthur, and Greta Burkart. We are indebted to pilots Hollis Twitchell, Dave Sowards, and Roger Kaye who always got us home safely, even when the weather had other plans. We thank Lucinda Lawson for helpful discussions related to this work and our two reviewers for comments that improved the manuscript.

\section{SUPPLEMENTARY MATERIAL}

The Supplementary Material for this article can be found online at: https://www.frontiersin.org/articles/10.3389/fevo. 2020.590837/full\#supplementary-material

Baumann, E. J. Jr., and Crowley, B. E. (2015). Stable isotopes reveal ecological differences amongst now-extinct proboscideans from the Cincinnati region, USA. Boreas 44, 240-254. doi: 10.1111/bor. 12091

Beard, B. L., and Johnson, C. M. (2000). Strontium isotope composition of skeletal material can determine the birth place and geographic mobility of humans and animals. JFS 45, 1049-1061. doi: 10.1520/JFS 14829J

Beaumont, W., Beverly, R., Southon, J., and Taylor, R. E. (2010). Nuclear instruments and methods in physics research B. Nuclear Inst. Methods Phys. Res. B 268, 906-909. doi: 10.1016/j.nimb.2009.10.061

Behrensmeyer, A. K. (1978). Taphonomic and ecologic information from bone weathering. Paleobiology 4, 150-162. doi: 10.1017/S00948373000 05820

Behrensmeyer, A. K., and Miller, J. H. (2012). "Building links between ecology and paleontology using taphonomic studies of recent vertebrate communities," in Paleontology in Ecology and Conservation, ed J. Louys (Berlin: Springer), 69-91. doi: 10.1007/978-3-642-25038-5_5

Behrensmeyer, A. K., Western, D., and Boaz, D. E. D. (1979). New perspectives in vertebrate paleoecology from a recent bone assemblage. Paleobiology 5, 12-21. doi: 10.1017/S0094837300006254

Benson, K. (2019). Gwichin Knowledge of Porcupine Caribou: State of Current Knowledge and Gaps Assessment. Fort McPherson, NT: Department of Cultural Heritage, Gwich'in Tribal Council.

Bentley, A. R. (2006). Strontium isotopes from the Earth to the archaeological skeleton: a review. J. Archaeol. Method Theor.13, 135-187. doi: 10.1007/s10816-006-9009-x

Berger, J. (2004). The last mile: how to sustain long-distance migration in mammals. Conserv. Biol. 18, 320-331. doi: 10.1111/j.1523-1739.2004.00548.x

Bergerud, A. T. (1976). The annual antler cycle in Newfoundland caribou. Can. Field Natural. 90, 449-463. 
Bergerud, A. T. (1996). Evolving perspectives on caribou population dynamics, have we got it right yet? Rangifer 16, 95-116. doi: 10.7557/2.16.4.1225

Bergerud, A. T., Luttich, S. N., and Camps, L. (2008). The Return of Caribou to Ungava. Montreal, QC: McGill Queens University Press. doi: 10.2307/j.ctt817j4

Blaauw, M. (2010). Methods and code for 'classical' age-modelling of radiocarbon sequences. Quat. Geochronol. 5, 512-518. doi: 10.1016/j.quageo.2010.01.002

Blaauw, M. (2019). Clam: Classical Age-Depth Modelling of Cores from Deposits. $\mathrm{R}$ package version 2.3.2. Available online at: https://cran.r-project.org/web/ packages/clam/index.html (accessed August 10, 2020).

Blake, J. E., Rowell, J. E., and Suttie, J. M. (1998). Characteristics of firstantler growth in reindeer and their association with seasonal fluctuations in steroid and insulin-like growth factor 1 levels. Can. J. Zool. 76, 2096-2102. doi: $10.1139 / \mathrm{z} 98-130$

Boertje, R. D. (1984). Seasonal diets of the Denali caribou herd, Alaska. Arctic 37, 161-165. doi: 10.14430/arctic2182

Boertje, R. D., and Gardner, C. L. (2000). The Fortymile caribou herd: novel proposed management and relevant biology, 1992-1997. Rangifer 17-37. doi: $10.7557 / 2.20 .5 .1622$

Bolger, D. T., Newmark, W. D., Morrison, T. A., and Doak, D. F. (2008). The need for integrative approaches to understand and conserve migratory ungulates. Ecol. Lett. 11, 63-77. doi: 10.1111/j.1461-0248.2007.01109.x

Brady, K. (2017). "H.R.1. An Act to provide for reconciliation pursuant to titles II and $\mathrm{V}$ of the concurrent resolution on the budget for fiscal year 2018," in 115th Congress of the United States of America (Washington, DC).

Britton, K., Britton, K., Grimes, V., Grimes, V., Niven, L., Niven, L., et al. (2011). Strontium isotope evidence for migration in late Pleistocene Rangifer: implications for neanderthal hunting strategies at the middle Palaeolithic site of Jonzac, France. J. Hum. Evol. 61, 176-185. doi: 10.1016/j.jhevol.2011. 03.004

Britton, K., Grimes, V., Dau, J., and Richards, M. P. (2009). Reconstructing faunal migrations using intra-tooth sampling and strontium and oxygen isotope analyses: a case study of modern caribou (Rangifer tarandus granti). J. Archaeol. Sci. 36, 1163-1172. doi: 10.1016/j.jas.2009.01.003

Bubenik, G. A., Schams, D., White, R. J., and Rowell, J. (1997). Seasonal levels of reproductive hormones and their relationship to the antler cycle of male and female reindeer (Rangifer tarandus). Comparat. Biochem. Physiol. B 116B, 269-277. doi: 10.1016/S0305-0491(97)00183-1

Burch, E. S. Jr. (2012). "Chapter 5. The northern district," in Caribou Herds of Northwest Alaska 1850-2000, eds I. Krupnik and J. Dau (Fairbanks, AK: University of Alaska Press).

Caikoski, J. (2020). Porcupine Caribou Herd Management Report and Plan, Game Management Units 25A, 25B, 25D, and 26C: Report Period 1 July 2012-30 June 2017, and Plan Period 1 July 2017-30 June 2022. Alaska Department of Fish and Game, Species Management Report and Plan ADF\&G/DWC/SMR\&P2020-22, Juneau, AK, United States.

Cameron, R. D., Reed, D. J., Dau, J., and Smith, W. (1992). Redistribution of calving caribou in response to oil field development on the Arctic Slope of Alaska. Arctic 45, 338-342. doi: 10.14430/arctic1412

Cameron, R. D., Smith, W. T., White, R. G., and Griffith, B. (2005). Central Arctic Caribou and petroleum development: distributional, nutritional, and reproductive implications. Arctic 58, 1-9. doi: 10.14430/arctic382

Cameron, R. D., and Whitten, K. R. (1979). Seasonal movements and sexual segregation of caribou determined by aerial survey. Arctic 43, 626-633. doi: $10.2307 / 3808740$

Cameron, R. D., and Whitten, K. R. (1980). Effects of the Trans-Alaska Pipeline on Caribou Movements. Juneau, AK: Department of Fish and Game.

Cameron, R. D., Smith, W. T., White, R. G., and Griffith, B. (2002). "Section 4: the Central Arctic caribou herd," in Arctic Refuge Coastal Plain Terrestrial Wildlife Research Summaries. Biological Science Report USGS/BRD/BSR-2002-0001, eds D. C. Douglas, P. E. Reynolds, and E. Rhode (Reston, VA: United States Geological Survey), 38-45.

Capo, R. C., Stewart, B. W., and Chadwick, O. A. (1998). Strontium isotopes as tracers of ecosystem processes: theory and methods. Geochem. Cosmochim. Acta 82, 197-225. doi: 10.1016/S0016-7061(97)00102-X

Colpron, M., Israel, S., Murphy, D., Pagage, L., and Moynihan, D. (2016). Yukon Bedrock Geology Map and Legend. Available online at: http://data.geology.gov. yk.ca/Reference/69477\#InfoTab (accessed November 14, 2020).
Couturier, S., Otto, R. D., Côté, S. D., Luther, G., and Mahoney, S. P. (2010). Body size variations in caribou ecotypes and relationships with demography. J. Wildlife Manage.74, 395-404. doi: 10.2193/2008-384

Crowley, B. E., Carter, M. L., Karpanty, S. M., Zihlman, A. L., Koch, P. L., and Dominy, N. J. (2010). Stable carbon and nitrogen isotope enrichment in primate tissues. Oecologia 164, 611-626. doi: 10.1007/s00442-010-1701-6

Crowley, B. E., Castro, I., Soarimalala, V., and Goodman, S. M. (2018). Isotopic evidence for niche partitioning and the influence of anthropogenic disturbance on endemic and introduced rodents in central Madagascar. Sci. Nat. 105:44. doi: 10.1007/s00114-018-1564-y

Crowley, B. E., Miller, J. H., and Bataille, C. P. (2017). Strontium isotopes $\left.{ }^{87} \mathrm{Sr} /{ }^{86} \mathrm{Sr}\right)$ in terrestrial ecological and palaeoecological research: empirical efforts and recent advances in continental-scale models. Biol. Rev. 92, 43-59. doi: 10.1111/brv.12217

Crowley, B. E., and Wheatley, P. V. (2014). To bleach or not to bleach? Comparing treatment methods for isolating biogenic carbonate. Chem. Geol. 381, 234-242. doi: 10.1016/j.chemgeo.2014.05.006

Curl, J. A. (2020). Central Arctic Caribou Herd News, Summer 2020. Fairbanks, AK: Alaska Department of Fish and Game, Division of Wildlife Conservation.

Dau, J. R., and Cameron, R. D. (1986). Effects of a road system on caribou distribution during calving. Rangifer 6, 95-101. doi: 10.7557/2.6.2.588

Dietl, G. P., Kidwell, S. M., Brenner, M., Burney, D. A., Flessa, K. W., Jackson, S. T., et al. (2015). Conservation paleobiology: leveraging knowledge of the past to inform conservation and restoration. Annu. Rev. Earth Planet. Sci. 43, 79-103. doi: 10.1146/annurev-earth-040610-133349

Dingle, H. (2006). Animal migration: is there a common migratory syndrome? J. Ornithol. 147, 212-220. doi: 10.1007/s10336-005-0052-2

Douglas, D. C., Reynolds, P. E., and Rhode, E. (2002). Arctic Refuge Coastal Plain Terrestrial Wildlife Research Summaries. Reston, VA: U.S. Geological Survey Biological Science Report USGS/BRD/BSR-2002-R-0001.

Espmark, Y. (1971). Antler shedding in relation to parturition in female reindeer. J. Wild Manage 35, 175-177. doi: 10.2307/3799887

Fancy, S. G. (1983). Movements and activity budgets of caribou near oil drilling sites in the Sagavanirktok River floodplain, Alaska. Arctic 36, 193-197. doi: 10.14430/arctic2262

Fancy, S. G., Pank, L. F., Whitten, K. R., and Regelin, W. L. (1989). Seasonal movements of caribou in arctic Alaska as determined by satellite. Can. J. Zool. 67, 644-650. doi: 10.1139/z89-093

Fancy, S. G., and Whitten, K. R. (1991). Selection of calving sites by Porcupine Herd Caribou. Can. J. Zool. 69, 1736-1743. doi: 10.1139/z91-242

Festa-Bianchet, M., Ray, J. C., Boutin, S., Côté, S. D., and Gunn, A. (2011). Conservation of caribou (Rangifer tarandus) in Canada: an uncertain future. Can. J. Zool. 89, 419-434. doi: 10.1139/z11-025

Fiorillo, A. R. (1995). The possible influence of low temperature on bone weathering in curecanti National recreation area, southwest Colorado. Curr. Res. Pleistocene 12, 69-71.

Flockhart, D. T. T., Kyser, T. K., Chipley, D., Miller, N. G., and Norris, D. R. (2015). Experimental evidence shows no fractionation of strontium isotopes $\left({ }^{87} \mathrm{Sr} /{ }^{86} \mathrm{Sr}\right)$ among soil, plants, and herbivores: implications for tracking wildlife and forensic science. Isotopes Environ. Health Stud. 51, 37-381. doi: $10.1080 / 10256016.2015 .1021345$

Froyd, C. A., and Willis, K. J. (2008). Emerging issues in biodiversity \& conservation management: the need for a palaeoecological perspective. Quat. Sci. Rev. 27, 1723-1732. doi: 10.1016/j.quascirev.2008.06.006

Fryxell, J. M., and Sinclair, A. R. E. (1988). Causes and consequences of migration by large herbivores. Trends Ecol. Evol. 3, 237-241. doi: 10.1016/0169-5347(88)90166-8

Gaglioti, B. V., Mann, D. H., Wiles, G. C., Jones, B. M., Charlton, J., Wiesenberg, N., et al. (2019). Timing and potential causes of 19th-century glacier advances in coastal Alaska based on tree-ring dating and historical accounts. Front. Earth Sci. 7:122. doi: 10.3389/feart.2019.00082

Gigleux, C., Grimes, V., Tütken, T., Knecht, R., and Britton, K. (2017). Reconstructing caribou seasonal biogeography in Little Ice Age (late Holocene) Western Alaska using intra-tooth strontium and oxygen isotope analysis. J. Archaeol. Sci. Rep. 23, 1043-1054. doi: 10.1016/j.jasrep.2017.10.043

Gotelli, N. J., and Ellison, A. M. (2004). A Primer of Ecological Statistics. Sunderland, MA: Sinauer Associates, Inc. 
Grace, M., Akçakaya, H. R., Bennett, E., Hilton-Taylor, C., Long, B., MilnerGulland, E. J., et al. (2019). Using historical and palaeoecological data to inform ambitious species recovery targets. Phil. Trans. R. Soc. B 374:20190297. doi: $10.1098 /$ rstb.2019.0297

Graversen, R. G., Mauritsen, T., Tjernström, M., Källén, E., and Svensson, G. (2008). Vertical structure of recent Arctic warming. Nature 541, 53-56. doi: $10.1038 /$ nature 06502

Griffith, B., Douglas, D. C., Walsh, N. E., Young, D. D., McCabe, T. R., Russell, D. E., et al. (2002). "Section 3: the porcupine caribou herd," in Arctic Refuge Coastal Plain Terrestrial Wildlife Research Summaries. Biological Science Report USGS/BRD/BSR-2002-0001, eds D. C. Douglas, P. E. Reynolds, and E. Rhode (Reston, VA: United States Geological Survey), 8-37.

Hall, B. K. (2005). Bones and Cartilage: Developmental and Evolutionary Skeletal Biology. 2nd ed. Halifax, NS: Academic Press. doi: 10.1016/B978-0-12-319060-4.50065-8

Helle, T., and Särkelä, M. (1993). The effects of outdoor recreation on range use by semi-domesticated reindeer. Scand. J. For. Res. 8, 123-133. doi: 10.1080/02827589309382761

Hinkes, M. T., Collins, G. H., and van Daele, L. J. (2005). Influence of population growth on caribou herd identity, calving ground fidelity, and behavior. J. Wildlife Manage. 69, 1147-1162. doi: 10.2193/0022-541X(2005)069[1147:IOPGOC]2.0.CO;2

Hobson, K. A., Barnett-Johnson, R., and Cerling, T. E. (2009). "Using isoscapes to track animal migration," in Understanding movement, pattern, and process on Earth through isotope mapping, eds J. B. West, G. J. Bowen, T. E. Dawson, and K. P. Tu (New York, NY: Springer), 273-298. doi: 10.1007/978-90-481-3354-3_13

Hoppe, K. A., and Koch, P. L. (2007). Reconstructing the migration patterns of late Pleistocene mammals from northern Florida, USA. Quat. Res. 68, 347-352. doi: 10.1016/j.yqres.2007.08.001

Hoppe, K. A., Koch, P. L., Carlson, R. W., and Webb, S. D. (1999). Tracking mammoths and mastodons: reconstruction of migratory behavior using strontium isotope ratios. Geology 27, 439-442. doi: 10.1130/0091-7613(1999)027<0439:TMAMRO>2.3.CO;2

Hospitaleche, C. A., Márquez, G., Pérez, L. M., Rosato, V., and Cione, A. L. (2011). Lichen bioerosion on fossil vertebrates from the Cenozoic of Patagonia and Antarctica. Ichnos 18, 1-8. doi: 10.1080/10420940.2011.552577

Høymork, A., and Reimers, E. (1999). Antler development in reindeer in relation to age and sex. Rangifer 22, 75-82. doi: 10.7557/2.22.1.692

Hua, Q., Barbetti, M., and Rakowski, A. Z. (2013). Atmospheric radiocarbon for the period 1950-2010. Radiocarbon 55, 2059-2072. doi: $10.2458 /$ azu_js_rc.v55i2.16177

IPCC (Intergovernmental Panel on Climate Change). (2014). "Climate change 2014: synthesis report," in Contribution of Working Groups I, II and III to the Fifth Assessment Report of the Intergovernmental Panel on Climate Change, eds R. K. Pachauri and L. A. Meyer (Geneva: Intergovernmental Panel on Climate Change). doi: 10.1017/CBO9781107415416

Johnson, C. J., and Russell, D. E. (2014). Long-term distribution responses of a migratory caribou herd to human disturbance. Biol. Conserv. 177, 52-63. doi: 10.1016/j.biocon.2014.06.007

Johnson, H. E., Golden, T. S., Adams, L. G., Gustine, D. D., and Lenart, E. A. (2020). Caribou use of habitat near energy development in Arctic Alaska. J. Wild. Mgmt. 84, 401-412. doi: 10.1002/jwmg.21809

Joly, K., Gurarie, E., Sorum, M. S., Kaczensky, P., Cameron, M. D., Jakes, A. F., et al. (2019). Longest terrestrial migrations and movements around the world. Sci. Rep. 9:15333. doi: 10.1038/s41598-019-51884-5

Joly, K., Klein, D. R., Verbyla, D. L., Rupp, T. S., and Chapin, F. S. (2011). Linkages between large-scale climate patterns and the dynamics of Arctic caribou populations. Ecography 34, 345-352. doi: 10.1111/j.1600-0587.2010. 06377.x

Joly, K., Nellemann, C., and Vistnes, I. (2006). A reevaluation of caribou distribution near an oilfield road on Alaska's North Slope. Wildl. Soc. Bull. 34, 866-869. doi: 10.2193/0091-7648(2006)34[866:AROCDN]2.0.CO;2

Jorgenson, J. C., and Walker, D. A. (2018). Land Cover and Vegetation Map, Arctic National Wildlife Refuge. Oak Ridge, TN: ORNL DAAC.

Jorgenson, J. C., Joria, P. E., and Douglas, D. C. (2002). “Section 2: land cover," in Arctic Regufe Coastal Plain Terrestrial Wildlife Research Summaries. Biological Science Report USGS/BRD/BSR-2002-0001, eds D. C. Douglas, P. E. Reynolds, and E. Rhode (Reston, VA: United States Geological Survey), 4-7.
Kidwell, S. M. (2007). Discordance between living and death assemblages as evidence for anthropogenic ecological change. Proc. Natl. Acad. Sci. U.S.A. 104, 17701-17706. doi: 10.1073/pnas.0707194104

Kidwell, S. M. (2015). Biology in the Anthropocene: challenges and insights from young fossil records. Proc. Natl. Acad. Sci U.S.A. 112, 4922-4929. doi: 10.1073 /pnas. 1403660112

Kidwell, S. M., and Tomasovych, A. (2013). Implications of time-averaged death assemblages for ecology and conservation biology. Annu. Rev. Ecol. Evol. Syst. 44, 539-563. doi: 10.1146/annurev-ecolsys-110512-135838

Klein, D. R. (1971). Reaction of reindeer to obstructions and disturbances. Science 173, 393-398. doi: 10.1126/science.173.3995.393

Koch, P. L., Heisinger, J., Moss, C. J., Carlson, R. W., Fogel, M. L., and Behrensmeyer, A. K. (1995). Isotopic tracking of change in diet and habitat use in African elephants. Science 267, 1340-1343. doi: $10.1126 /$ science.267.5202.1340

Lawhead, B. E., and Prichard, A. K. (2003). Surveys of Caribou and Muskoxen in the Kuparuk-Colville Region, Alaska, 2002. Fairbanks, AK: Final Report prepared for ConocoPhillips Alaska, Inc. ABR, Inc.

Lenart, E. A. (2015). "Chapter 18: units 26B and 26C caribou," in Caribou Management Report of survey and Inventory Activities 1 July 2012-30 June 2014, eds P. Harper and L. A. McCarthy (Juneau, AK: Alaska Department of Fish and Game, Species Management Report ADF\&G/DWC/SMR-2015-4), 1-38.

Lewis, J., Pike, A. W. G., Coath, C. D., and Evershed, R. P. (2017). Strontium concentration, radiogenic $\left({ }^{87} \mathrm{Sr} /{ }^{86} \mathrm{Sr}\right)$ and stable $\left(\delta^{88} \mathrm{Sr}\right)$ strontium isotope systematics in a controlled feeding study. STAR Sci. Tech. Archaeol. Res. 3, 45-57. doi: 10.1080/20548923.2017.1303124

Ma, C., Vander Zanden, H. B., Wunder, M. B., and Bowen, G. J. (2020). assignR: an R package for isotope-based geographic assignment. Methods Ecol. Evol. 111, 996-1001. doi: 10.1111/2041-210X.13426

Magurran, A. E., Baillie, S. R., Buckland, S. T., Dick, J. M., Elston, D. A., Scott, E. M., et al. (2010). Long-term datasets in biodiversity research and monitoring: assessing change in ecological communities through time. Trends Ecol. Evol. 25, 574-582. doi: 10.1016/j.tree.2010.06.016

Makarewicz, C. A., and Sealy, J. (2015). Dietary reconstruction, mobility, and the analysis of ancient skeletal tissues: expanding the prospects of stable isotope research in archaeology. J. Archaeol. Sci. 56, 146-158. doi: 10.1016/j.jas.2015.02.035

McFarland, H. R., Caikoski, J., Lenart, E., and Taras, M. (2017). Porcupine Caribou News, Summer 2017. Fairbanks, AK: Alaska Department of Fish and Game; Division of Wildlife Conservation.

Meldgaard, M. (1986). The Greenland caribou - zoogeography, taxonomy, and population dynamics. Meddelelser Gronland 20, 1-89.

Mihoub, J.-B., Henle, K., Titeux, N., Brotons, L., Brummitt, N. A., and Schmeller, D. S. (2017). Setting temporal baselines for biodiversity: the limits of available monitoring data for capturing the full impact of anthropogenic pressures. Sci. Rep. 7:41591. doi: 10.1038/srep41591

Miller, F. L., and Barry, S. J. (1992). Nonrandom distribution of antlers cast by Peary caribou bulls, Melville Island, Northwest Territories. Arctic 45, 252-257. doi: 10.14430/arctic1399

Miller, J. H. (2009). The Large-Mammal Death Assemblage of Yellowstone National Park: Historical Ecology, Conservation Biology, Paleoecology (Ph.D. Dissertation). University of Chicago, Chicago, IL.

Miller, J. H. (2011). Ghosts of yellowstone: multi-decadal histories of wildlife populations captured by bones on a modern landscape. PLOS ONE 6:e18057. doi: 10.1371/journal.pone.0018057

Miller, J. H. (2012). Spatial fidelity of skeletal remains: elk wintering and calving grounds revealed by bones on the Yellowstone landscape. Ecology 93, 2474-2482. doi: 10.1890/12-0272.1

Miller, J. H., Behrensmeyer, A. K., Du, A., Lyons, S. K., Patterson, D., Tóth, A., et al. (2014). Ecological fidelity of functional traits based on species presence-absence in a modern mammalian bone assemblage (Amboseli, Kenya). Paleobiology 40, 560-583. doi: 10.1666/13062

Miller, J. H., Druckenmiller, P., and Bahn, V. (2013). Antlers on the Arctic Refuge: capturing multi-generational patterns of calving ground use from bones on the landscape. Proc. R. Soc. B 280:20130275. doi: 10.1098/rspb.2013.0275

Morneau, C., and Payette, S. (1998). A dendroecological method to evaluate past caribou (Rangifer tarandus L.) activity. Écoscience 5, 64-76. doi: 10.1080/11956860.1998.11682446 
Morneau, C., and Payette, S. (2000). Long-term fluctuations of a caribou population revealed by tree-ring data. Can. J. Zool. 78, 1784-1790. doi: $10.1139 / z 00-122$

Nash, T. H. III. (2008). Lichen Biology. 2nd ed. Cambridge: Cambridge University Press. doi: 10.1017/CBO9780511790478

Nicholson, K. L., Arthur, S. M., Horne, J. S., Garton, E. O., and Del Vecchio, P. A. (2016). Modeling caribou movements: seasonal ranges and migration routes of the Central Arctic Herd. PLoS ONE 11:e0150333. doi: 10.1371/journal.pone. 0150333

PCMB (Porcupine Caribou Management Board). (2016). Porcupine Caribou Annual Summary Report 2016. Whitehorse, YT: Porcupine Caribou Management Board.

Pearce, J. M., Flint, P. L., Atwood, T. C., Douglas, D. C., Adams, L. G., Johnson, H. E., et al. (2018). Summary of Wildlife-Related Research on the Coastal Plain of the Arctic National Wildlife Refuge, Alaska, 2002-17. Reston, VA: U.S. Department of the Interior. doi: 10.3133/ofr20181003

Peters, W., Hebblewhite, M., Mysterud, A., Spitz, D., Focardi, S., Urbano, F., et al. (2017). Migration in geographic and ecological space by a large herbivore. Ecol. Monogr. 87, 297-320. doi: 10.1002/ecm.1250

Pokines, J. T., Faillace, K., Berger, J., Pirtle, D., Sharpe, M., Curtis, A., et al. (2018). The effects of repeated wet-dry cycles as a component of bone weathering. J. Arch. Sci. Rep. 17, 433-441. doi: 10.1016/j.jasrep.2017.11.025

Pokines, J. T., King, R. E., Graham, D. D., Costello, A. K., Adams, D. M., Pendray, J. M., et al. (2016). The effects of experimental freeze-thaw cycles to bone as a component of subaerial weathering. JASREP 6, 594-602. doi: 10.1016/j.jasrep.2016.03.023

Post, E., and Stenseth, N. C. (1998). Large-scale climatic fluctuation and population dynamics of moose and white-tailed deer. J. Anim. Ecol. 67, 537-543. doi: 10.1046/j.1365-2656.1998.00216.x

Prichard, A. K., Parrett, L. S., Lenart, E. A., Caikoski, J. R., Joly, K., and Person, B. T. (2020). Interchange and overlap among four adjacent arctic caribou herds. J. Wildlife Manage. 84, 1500-1514. doi: 10.1002/jwmg.21934

R Core Team. (2017). R: A language and environment for statistical computing. Vienna: R Foundation for Statistical Computing. Available online at: https:// www.R-project.org/ (accessed June 30, 2017).

Reimer, P. J., Bard, E., Bayliss, A., Beck, J. W., Blackwell, P. G., Ramsey, C. B., et al. (2013). IntCal13 and marine13 radiocarbon age calibration curves 0-50,000 years cal BP. Radiocarbon 55, 1869-1887. doi: 10.2458/azu_js_rc.55.16947

Reimer, P. J., Brown, T. A., and Reimer, R. W. (2004). Discussion: reporting and calibration of post-bomb ${ }^{14} \mathrm{C}$ data. Radiocarbon 46, 1299-1304. doi: $10.1017 /$ S0033822200033154

Rowe, R. J., and Terry, R. C. (2014). Small mammal responses to environmental change: integrating past and present dynamics. J. Mammal. 95, 1157-1174. doi: 10.1644/13-MAMM-S-079

Russell, D., and Gunn, A. (2019). Vulnerability Analysis of the Porcupine Caribou Herd to Potential Development of the 1002 lands in the Arctic National Wildlife Refuge, Alaska. Report prepared for: Environment Yukon, Canadian Wildlife Service, and GNWT Department of Environment and Natural Resources, 143.

Russell, D. E., Martell, A. M., and Nixon, W. A. C. (1993). Range ecology of the Porcupine Caribou Herd in Canada. Rangifer Special Issue 8, 1-168. doi: 10.7557/2.13.5.1057

Russell, D. E., White R. G., and Daniel, C. J. (2005). Energetics of the Porcupine Caribou Herd: A Computer Simulation Model. Technical Report Series No. 431. Ottawa, ON: Canadian Wildlife Service.

Schaefer, J. A., and Mahoney, S. P. (2003). Spatial and temporal scaling of population density and animal movement: a power law approach. Ecoscience 10, 496-501. doi: 10.1080/11956860.2003.11682797

Schaefer, J. A., and Mahoney, S. P. (2013). Spatial dynamics of the rise and fall of caribou (Rangifer tarandus) in Newfoundland. Can. J. Zool. 91, 767-774. doi: 10.1139/cjz-2013-0132

Sikorski, J. J., Kaufman, D. S., Manley, W. F., and Nolan, M. (2009). Glacial-geologic evidence for decreased precipitation during the Little Ice Age in the Brooks Range, Alaska. Arct. Antarct. Alp. Res. 41, 138-150. doi: 10.1657/1523-0430-41.1.138

Skoog, R. O. (1968). Ecology of the caribou (Rangifer tarandus granti) in Alaska (Ph.D. Dissertation). Berkeley, CA: University of California Berkeley.

Sokal, R. R., and Rohlf, F. J. (2011). Biometry. 3rd ed. New York, NY: W. H. Freeman and Company.
Solomina, O. N., Bradley, R. S., Hodgson, D. A., Ivy-Ochs, S., Jomelli, V., Mackintosh, A. N., et al. (2015). Holocene glacier fluctuations. Quat. Sci. Rev. 111, 9-34. doi: 10.1016/j.quascirev.2014.11.018

Sutcliffe, A. J., and Blake, W. (2000). Biological activity on a decaying caribou antler at Cape Herschel, Ellesmere Island, Nunavut, high Arctic Canada. Polar Record. 233-246. doi: 10.1017/S0032247400016491

Taillon, J., Festa-Bianchet, M., and Côté, S. D. (2012). Shifting targets in the tundra: protection of migratory caribou calving grounds must account for spatial changes over time. Biol. Conserv. 147, 163-173. doi: $10.1016 /$ j.biocon.2011.12.027

Tappen, M. (1994). Bone weathering in the tropical rain forest. J. Archaeol. Sci. 21, 667-673. doi: 10.1006/jasc.1994.1066

Tappen, M. (1995). Savanna ecology and natural bone deposition: implications for early hominid site formation, hunting, and scavenging. Curr. Anthropol. 36, 223-260. doi: 10.1086/204353

Telford, R. J., Heegaard, E., and Birks, H. J. B. (2004). The intercept is a poor estimate of a calibrated radiocarbon age. Holocene 14, 296-298. doi: 10.1191/0959683604hl707fa

Terry, R. C. (2009). The dead do not lie: using skeletal remains for rapid assessment of historical small-mammal community baselines. Proc. $R$ Soc. $B$ 324, 1061-1064. doi: 10.1098/rspb.2009.1984

Thompson, D. C., and McCourt, K. H. (1981). Seasonal diets of the Porcupine Caribou Herd. Am. Midl. Nat. 105:70. doi: 10.2307/2425011

Todisco, D., and Monchot, H. (2008). Bone weathering in a periglacial environment: the Tayara Site (KbFk-7), Qikirtaq Island, Nunavik (Canada). Arctic 61, 87-101. doi: 10.14430/arctic9

Tomasovych, A., and Kidwell, S. M. (2017). Nineteenth-century collapse of a benthic marine ecosystem on the open continental shelf. Proc. R. Soc. B 284:20170328. doi: 10.1098/rspb.2017.0328

Trammell, E. J., Carlson, M. L., Fresco, N., Gotthardt, T., McTeague, M. L., and Vadapalli, D. (eds.). (2015). North Slope Rapid Ecoregional Assessment. Prepared for the Bureau of Land Management. Anchorage, AK: U.S. Department of the Interior.

Tucker, M. A., Böhning-Gaese, K., Fagan, W. F., Fryxell, J. M., van Moorter, B., Alberts, S. C., et al. (2018). Moving in the Anthropocene: global reductions in terrestrial mammalian movements. Science 359, 466-469. doi: $10.1126 /$ science.aam 9712

U.S. Fish and Wildlife Service. (2015). "Chapter 4: affected environment," in Arctic National Wildlife Refuge Revised Comprehensive Conservation Plan (Fairbanks, AK: U.S. Fish and Wildlife Service), 255.

Udall, M. (1980). "H.R.39. Alaska national interest lands conservation act," in 96th Congress of the United States of America (Washington, DC).

Uno, K. T., Quade, J., Fisher, D. C., Wittemyer, G., Douglas-Hamilton, I., Andanje, S., et al. (2013). Bomb-curve radiocarbon measurement of recent biologic tissues and applications to wildlife forensics and stable isotope (paleo)ecology. Proc. Natl. Acad. SciU.S.A. 110, 11736-11741. doi: 10.1073/pnas.1302226110

USA-Canada. (1987). Agreement Between the Government of Canada and the Government of the United States of America on the Conservation of the Porcupine Caribou Herd. Washington, DC: Government of the United States of America.

Vistnes, I., and Nellemann, C. (2008). The matter of spatial and temporal scales: a review of reindeer and caribou response to human activity. Polar Biol. 31, 399-407. doi: 10.1007/s00300-007-0377-9

Vors, L., Schaefer, J., Pond, B., Rodgers, A., and Patterson, B. (2010). Woodland caribou extirpation and anthropogenic landscape disturbance in Ontario. $J$. Wild. Manage 71, 1249-1256. doi: 10.2193/2006-263

Vors, L. S., and Boyce, M. S. (2009). Global declines of caribou and reindeer. Glob. Chang. Biol. 15, 2626-2633. doi: 10.1111/j.1365-2486.2009.01974.x

Western, D., and Behrensmeyer, A. K. (2009). Bone assemblages track animal community structure over 40 years in an African savanna ecosystem. Science 324, 1061-1064. doi: 10.1126/science.1171155

Whitten, K. R. (1994). "International cooperation in managing the Porcupine Caribou Herd," in 74th Annual Conference Westen Association of Fish and Wildlife Agencies (Alaska), 64-68.

Whitten, K. R. (1995). Antler loss and udder distention in relation to parturition in caribou. J. Wild Manage 59, 273-277. doi: 10.2307/3808940

Whitten, K. R., and Cameron, R. D. (1983). Population dynamics of the Central Arctic Herd, 1975-1981. Acta Zool. Fennica 175, 159-161. 
Whitten, K. R., Garner, G. W., and Mauer, F. J. (1984). "Calving distribution, initial productivity, and neonatal mortality of the Porcupine Caribou Herd, 1983," in Arctic National Wildlife Refuge Coastal Plain Resource Assessment, 1983 Update Report Baseline Study of the Fish, Wildlife, and Their Habitats, eds G. W. Garner and P. E. Reynolds (Anchorage, AK: United States Fish and Wildlife Service), 359-420.

Whitten, K. R., Garner, G. W., Mauer, F. J., and Harris, R. B. (1992). Productivity and early calf survival in the Porcupine caribou herd. J. Wild Manage. 201-212. doi: $10.2307 / 3808814$

Widga, C., Walker, J. D., and Boehm, A. (2017). Variability in bioavailable ${ }^{87} \mathrm{Sr} /{ }^{86} \mathrm{Sr}$ in the North American midcontinent. Open Quat. 3, 4-7. doi: 10.5334/oq.32

Wilson, F. H., Hultz, C. P., Mull, C. G., and Karl, S. M. (2015). Geologic Map of Alaska. U.S.: Geological Survey Scientific Investigations Map 3340. doi: $10.3133 / \operatorname{sim} 3340$

Wilson, R., Parrett, L., Joly, K., and Dau, J. (2016). Effects of roads on individual caribou movements during migration. Biol. Conserv. 195, 2-8. doi: 10.1016/j.biocon.2015.12.035
Zalatan, R., Gunn, A., and Henry, G. H. R. (2006). Long-term abundance patterns of barren-ground caribou using trampling scars on roots of Picea mariana in the Northwest Territories, Canada. Arct. Antarct. Alp. Res. 38, 624-630. doi: 10.1657/1523-0430(2006)38[624:LAPOBC] 2.0.CO;2

Conflict of Interest: The authors declare that the research was conducted in the absence of any commercial or financial relationships that could be construed as a potential conflict of interest.

Copyright (c) 2021 Miller, Crowley, Bataille, Wald, Kelly, Gaetano, Bahn and Druckenmiller. This is an open-access article distributed under the terms of the Creative Commons Attribution License (CC BY). The use, distribution or reproduction in other forums is permitted, provided the original author(s) and the copyright owner(s) are credited and that the original publication in this journal is cited, in accordance with accepted academic practice. No use, distribution or reproduction is permitted which does not comply with these terms. 